\title{
Observations of the diurnal and seasonal trends in nitrogen oxides in the western Sierra Nevada
}

\author{
J. G. Murphy ${ }^{1, *}$, D. A. Day ${ }^{1, * *}$, P. A. Cleary ${ }^{1,{ }^{* * *}}$, P. J. Wooldridge ${ }^{1}$, and R. C. Cohen ${ }^{1}$ \\ ${ }^{1}$ Department of Chemistry, University of California, Berkeley, USA \\ *now at: School of Environmental Sciences, University of East Anglia, Norwich, UK \\ *** now at: Department of Land, Air, and Water Resources, University of California, Davis, USA \\ **** now at: Department of Chemistry, University of Pennsylvania, Philadelphia, USA
}

Received: 6 February 2006 - Published in Atmos. Chem. Phys. Discuss.: 7 June 2006

Revised: 18 October 2006 - Accepted: 17 November 2006 - Published: 27 November 2006

\begin{abstract}
Observations of speciated nitrogen oxides, namely $\mathrm{NO}_{2}$, total peroxy nitrates ( $\Sigma \mathrm{PNs}$ ), total alkyl nitrates ( $\Sigma \mathrm{ANs}$ ), and $\mathrm{HNO}_{3}$ by thermal dissociation laser induced fluorescence (TD-LIF), and supporting chemical and meteorological measurements at Big Hill $(1860 \mathrm{~m})$, a high elevation site in California's Sierra Nevada Mountains, are described. From May through October, terrain-driven winds in the region routinely bring air from Sacramento, $100 \mathrm{~km}$ southwest of the site, upslope over oak and pine forests to Big Hill during the day, while at night, the site often samples clean, dry air characteristic of the free troposphere. Winter differs mainly in that the meteorology does not favour the buildup of Sacramento's pollution over the Sierra Nevada range, and the urban-influenced air that is seen has been less affected by biogenic VOC emissions, resulting in longer lifetime for $\mathrm{NO}_{2}$ and a predominance of the inorganic forms of nitrogen oxides.
\end{abstract}

Summertime observations at Big Hill can be compared with those from Granite Bay, a Sacramento suburb, and from the University of California's Blodgett Forest Research Station to examine the evolution of nitrogen oxides and ozone within the urban plume. Nitrogen oxide radicals (NO and $\left.\mathrm{NO}_{2}\right)$, which dominate total nitrogen oxides $\left(\mathrm{NO}_{\mathrm{y}}\right)$ at Granite Bay, are rapidly converted into $\mathrm{HNO}_{3}, \Sigma \mathrm{PNs}$, and $\Sigma$ ANs, such that these compounds contribute 29,30 , and $21 \%$ respectively to the $\mathrm{NO}_{\mathrm{y}}$ budget in the plume at Big Hill. Nevertheless, the decreasing concentrations of $\mathrm{NO}_{2}$ as the plume is advected to Big Hill lead to decreases in the production rate of $\mathrm{HNO}_{3}$ and ozone. The data also demonstrate the role that temperature plays in sequestering $\mathrm{NO}_{2}$ into peroxy nitrates, effectively decreasing the rate of ozone production. The important contribution of $\Sigma$ ANs to $\mathrm{NO}_{\mathrm{y}}$ in the region suggests that they should be considered with regards to ex-

Correspondence to: R. C. Cohen

(cohen@cchem.berkeley.edu) port of $\mathrm{NO}_{\mathrm{y}}$ from the boundary layer. Nocturnal observations of airmasses characteristic of the free troposphere showed lower $\mathrm{NO}_{\mathrm{y}}$ concentrations, which were dominated by $\mathrm{HNO}_{3}$ with a relatively small contribution from the organic nitrates.

\section{Introduction}

Anthropogenic activity increases the abundance of nitrogen oxides $\left(\mathrm{NO}_{\mathrm{x}}\right)$ in an urban atmosphere by orders of magnitude above global and regional background levels. After entering the atmosphere, nitrogen oxides are diluted and chemically processed on timescales of minutes to hours. In daylight, $\mathrm{NO}_{\mathrm{x}}$ is quickly interconverted between its two forms, $\mathrm{NO}$ and $\mathrm{NO}_{2}$, and in the presence of $\mathrm{OH}$ and volatile organic compounds (VOC), catalytic ozone production ensues. When the cycle is terminated by association reactions between $\mathrm{NO}_{\mathrm{x}}$ and odd hydrogen radicals $\left(\mathrm{HO}_{\mathrm{x}} \equiv \mathrm{OH}+\mathrm{HO}_{2}+\mathrm{RO}_{2}\right)$, higher oxides of nitrogen $\left(\mathrm{NO}_{\mathrm{z}}\right)$ are formed. The more oxidized $\mathrm{NO}_{\mathrm{z}}$ species may act as reservoirs or sinks for the $\mathrm{NO}_{\mathrm{x}}$ radicals, and in some instances gas to aerosol conversion results in the formation of nitrate particles. Because of the timescale of this photochemistry, rural and remote regions downwind of major $\mathrm{NO}_{\mathrm{x}}$ sources are often more severely affected by secondary pollutants, such as ozone or particulate matter, than the source area (e.g. White et al., 1976; Blumenthal et al., 1978; Trainer et al., 1995; Ryerson et al., 2001; Dillon et al., 2002; Neuman et al., 2003; Zaveri et al., 2003).

Observations at many remote continental locations show that the concentration and speciation of total reactive nitrogen oxides $\left(\mathrm{NO}_{\mathrm{y}}=\mathrm{NO}_{\mathrm{x}}+\mathrm{NO}_{\mathrm{z}}\right)$ are strongly influenced by meteorological conditions. At many sites in eastern North America concentrations of primary and secondary pollutants depend strongly on wind direction and season (Fahey et al.,

Published by Copernicus GmbH on behalf of the European Geosciences Union. 
1986; Munger et al., 1998; Hayden et al., 2003). During summer months there is a strong correlation observed between ozone and $\mathrm{NO}_{\mathrm{z}}$ (Trainer et al., 1993; Thornberry et al., 2001; Zaveri et al., 2003). Measurements from a high elevation site in the Swiss Alps show concentrations are governed by the relative contributions from polluted airmasses originating over continental Europe and cleaner airmasses from the free troposphere (Zellweger et al., 2003). As the transboundary nature of air pollution becomes better appreciated, there is an increasing impetus to quantify the export of reactive nitrogen oxides between continents (Liang et al., 1998; Li et al., 2004; Parrish et al., 2004), and the role it may play in affecting downwind air quality ( $\mathrm{Li}$ et al., 2002; Hudman et al., 2004). This requires a complete understanding of the factors that govern the chemistry, mixing and losses of nitrogen oxides over the appropriate timescales.

This paper describes speciated $\mathrm{NO}_{\mathrm{y}}$ data obtained at three sites located along an east-west transect between Sacramento and Lake Tahoe, California. The measurement sites are located downwind of Sacramento during daylight hours, in the outflow of its urban plume. The goals of our analysis are to examine the seasonal and diurnal cycles in nitrogen oxide compounds at the most remote site, Big Hill, and to compare the summertime measurements made at all three sites. This comparison allows us to investigate the role that nitrogen oxides play in regional ozone formation and to quantify the distribution of $\mathrm{NO}_{\mathrm{y}}$ available for export from the region. In Sect. 2 we provide details about the location, characteristics, and instrumentation of the three measurement sites. Section 3 explains the thermal dissociation laser-induced fluorescence technique used to make measurements of speciated nitrogen oxides at each of the sites. The regional meteorology is described in Sect. 4, both in terms of its seasonality, and the orographically driven diurnal cycle that drives air from the urban area towards the remote, high elevation Sierra Nevada during the day. Section 5 begins with a description of the annual cycle (March 2003-February 2004) of nitrogen oxide measurements made at Big Hill. In Sects. 5.3-5.5, we include measurements from two other sites: the nearby University of California Blodgett Forest Research Station (UCBFRS) and from Granite Bay, a Sacramento suburb. Summertime data from 2001 for the latter sites are compared with Big Hill data from the summer of 2003. Long term measurements of climate variables and ozone at UC-BFRS show that there is relatively little interannual variability between summers, and these two years in particular are very similar. Furthermore, routine monitoring of ozone and $\mathrm{NO}_{2}$ at Folsom, a site close to Granite Bay, shows that the chemical characteristics of the airmasses advecting east from Sacramento were very similar in both years also. Therefore we are able to use data from the three sites to examine the physical and chemical variables that determine the processing and distribution of nitrogen oxides in an airmass as it moves away from an urban area.

\section{Measurement sites}

The Big Hill monitoring site $\left(38.84^{\circ} \mathrm{N}, 120.41^{\circ} \mathrm{W}, 1860 \mathrm{~m}\right)$ is located in Eldorado National Forest in Placer County, California and was continuously maintained from March 2003 to February 2004. The site is located within a 24000 acre forest fire scar from the Cleveland Fire of 1992 and there remains minimal vegetation within $1 \mathrm{~km}$ of Big Hill. The site is approximately $5 \mathrm{~km}$ north of Highway 50 and $30 \mathrm{~km}$ south west of Lake Tahoe. A climate-controlled $9 \mathrm{~m}$ long trailer was used to house the trace gas instruments and was positioned on the west side of the hill, upwind of nearby structures (fire lookout tower, heliport) during the daytime hours. Sampling inlets were mounted using a tower on the trailer roof, approximately $5 \mathrm{~m}$ above ground level.

The details of the thermal dissociation laser-induced fluorescence (TD-LIF) instrument used to measure reactive nitrogen species and its performance characteristics during the Big Hill measurement campaign are described below. In addition to the measurements of $\mathrm{NO}_{\mathrm{yi}}$ species carried out by TD-LIF, California Air Resources Board (CARB) maintained a meteorological station (Met One Instruments) to measure temperature, humidity and wind speed and direction. Inside the trailer, CARB had two beta-attenuation monitors (BAMs, Met One Instruments) to measure particulate matter with diameters less than 2.5 and $10 \mu \mathrm{m}\left(\mathrm{PM}_{2.5}\right.$ and $\mathrm{PM}_{10}$ ), and commercial instrumentation to measure $\mathrm{NO}_{\mathrm{x}}$ and $\mathrm{NO}_{\mathrm{y}}$ (Teco 42CY), CO (API 300), and $\mathrm{O}_{3}$ (API 400). Unfortunately, the $\mathrm{CO}$ instrument did not have sufficient sensitivity, and the CARB $\mathrm{NO}_{\mathrm{xy}}$ data were not recorded with sufficient precision to yield useful values at this remote site.

Twenty kilometers northwest of the Big Hill site, the University of California operates a research site at Blodgett Forest (UC-BFRS) within a managed ponderosa pine plantation located at $38.88^{\circ} \mathrm{N}, 120.62^{\circ} \mathrm{W}$. Instruments are housed within a climate-controlled trailer and inlets are positioned at the top of a $10 \mathrm{~m}$ tower nearby. Measurements of reactive nitrogen have been made at the site using TD-LIF semicontinuously between October 2000 and October 2005. Additionally, long-term records exist for meteorological variables, $\mathrm{CO}_{2}, \mathrm{CO}$, ozone and several VOC. The main differences between the two sites are that UC-BFRS is at a significantly lower elevation, $1315 \mathrm{~m}$, is $20 \mathrm{~km}$ closer to Sacramento, and is surrounded by dense vegetation. These factors have a dramatic influence on the meteorology and chemistry at the sites, and consequently on the partitioning of reactive nitrogen.

During the summer of 2001, observations were made from a site at the northeastern edge of the Sacramento area in Granite Bay $\left(38.74^{\circ} \mathrm{N}, 121.20^{\circ} \mathrm{W}, 277 \mathrm{~m}\right)$. This site was ideally positioned to allow characterization of the initial conditions of the urban plume as it left the populated region and moved upslope. Figure 1 shows the location of all three monitoring sites. The instruments at Granite Bay were housed in the same mobile laboratory trailer that was later used at Big 


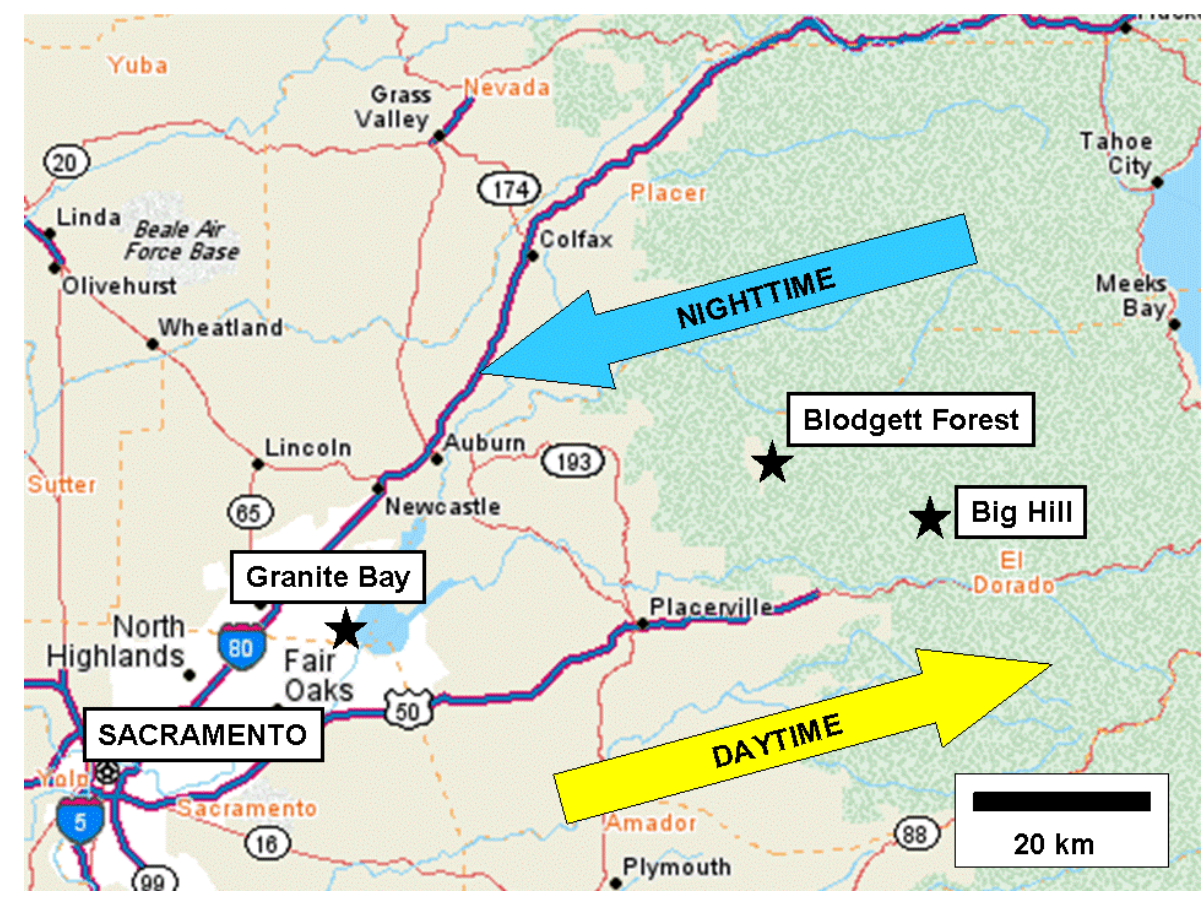

Fig. 1. Map of western Sierra Nevada region between Sacramento and Lake Tahoe, CA. Monitoring sites used in this paper include Granite Bay, a northeastern suburb of Sacramento, and Blodgett Forest (UC-BFRS) and Big Hill, located in the mid-elevation Sierra Nevada. Arrows depict the general daytime upslope, nighttime downslope flow pattern which dominates in the region.

Hill. A prototype LIF instrument measured $\mathrm{NO}_{2}$ continuously (Cleary et al., 2002), while a second TD-LIF instrument obtained measurements of $\mathrm{NO}_{2}$ and the individual $\mathrm{NO}_{\mathrm{Z}}$ species (Cleary et al., 2005). In this analysis, we also make use of ozone measurements (Dasibi, 1008) from that site.

\section{TD-LIF instrument for $\mathrm{NO}_{\mathrm{y}}$}

Thermal dissociation laser-induced fluorescence was used to make specific, rapid, cross-calibrated measurements of $\mathrm{NO}_{2}$, the sum of peroxy nitrate species $\left(\Sigma \mathrm{PNs} \equiv \mathrm{RO}_{2} \mathrm{NO}_{2}\right)$, the sum of alkyl nitrate species $\left(\Sigma \mathrm{ANs} \equiv \mathrm{RONO}_{2}\right)$, and $\mathrm{HNO}_{3}$. Heated ovens thermally decompose the organic nitrates and nitric acid to $\mathrm{NO}_{2}$ at temperatures characteristic of the compounds $\mathrm{XO}-\mathrm{NO}_{2}$ bond energy (Day et al., 2002). At ambient temperatures, only $\mathrm{NO}_{2}$ is responsible for the instrument signal. When the sample stream is heated to $180^{\circ} \mathrm{C}$ for approximately $100 \mathrm{~ms}$, the peroxy nitrates thermally decompose to yield $\mathrm{NO}_{2}$. By subtracting the ambient $\mathrm{NO}_{2}$ from the total $\mathrm{NO}_{2}$ measured after heating, the concentration of peroxy nitrates can be calculated. In a similar fashion, the air stream is heated to $330^{\circ} \mathrm{C}$ to dissociate alkyl nitrates and $550^{\circ} \mathrm{C}$ for $\mathrm{HNO}_{3}$. The TD-LIF instrument at Big Hill had two ovens. The ovens were cycled through temperature pairs to make measurements of each class of $\mathrm{NO}_{\mathrm{y}}$, for example one oven at $550^{\circ} \mathrm{C}$ and the second at $330^{\circ} \mathrm{C}$ to make a measurement of $\mathrm{HNO}_{3}$. The inlet system was housed in a $1.7 \mathrm{~m}$ long, $10 \mathrm{~cm} \times 10 \mathrm{~cm}$ steel box mounted vertically to a tower on the trailer roof. The individual nitrogen oxide compounds $\left(\mathrm{NO}_{\mathrm{yi}}\right)$ are converted to $\mathrm{NO}_{2}$ immediately after entering the inlet to minimize sampling losses. Aside from the oven sections, which are made of quartz, all the tubing in the inlet system is made of PFA, including the $10 \mathrm{~m}$ long lines that delivered the air from the rooftop inlet to the instrument inside the trailer.

Laser-induced fluorescence is a highly sensitive and selective method for detecting $\mathrm{NO}_{2}$ in the atmosphere (Thornton et al., 2000, 2003). In the configuration used here, a $\mathrm{Nd}$ :YAG-pumped dye laser operating at $585 \mathrm{~nm}$ is used to excite a particular rovibronic feature in the $\mathrm{NO}_{2}$ spectrum. The resulting fluorescence in each of two cells is collected by photomultiplier tubes with laser scatter and background light reduced by bandpass filters and time-gated detection. The sensitivity was also enhanced by use of a supersonic expansion in which the gas stream is expanded into low pressure $(<0.3$ Torr) through a critical orifice. The resulting thermal cooling of the gas forces a greater fraction of the $\mathrm{NO}_{2}$ molecules being sampled to absorb at the wavelength of light provided by the dye laser and results in a stronger fluorescence signal. Measurements were made at a rate of $1 \mathrm{~Hz}$ with an average detection limit throughout the campaign of $15 \mathrm{ppt} / \mathrm{s}(\mathrm{S} / \mathrm{N}=2)$.

Careful effort was made to ensure the accuracy and precision of the measurements made by TD-LIF. A zero air 


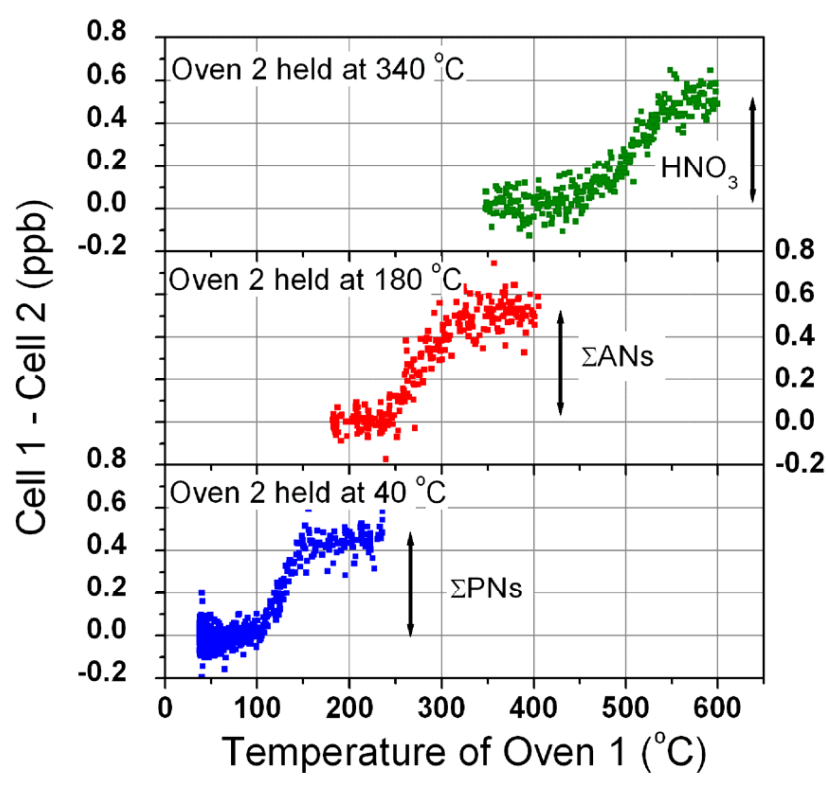

Fig. 2. The y-axis shows how the difference between concentrations of $\mathrm{NO}_{2}$ being measured in cells 1 and 2 changes as oven 1 is ramped from a temperature well above oven 2 down to the same temperature. For example, the lower panel shows that when cells 1 and 2 have their ovens set to 180 and $40^{\circ} \mathrm{C}$, respectively, the concentration difference between them can be attributed to peroxy nitrates. When the temperature of oven 1 is slowly reduced to be the same as oven 2 the two cells agree on average. Each datapoint represents a 3-s average during a scan of the ambient atmosphere at Big Hill.

generator (Sabio 1000) was used to provide clean air free of nitrogen oxides for zeros and calibrations. Zeros were performed approximately every two hours and were programmed to occur at every temperature setting. A NISTtraceable cylinder of $5.17 \mathrm{ppm} \mathrm{NO} \mathrm{NO}_{2}$ (BOC gases) was used for calibration of the instrument every three hours. Mass flow controllers (MKS) were used to dilute the $\mathrm{NO}_{2}$ standard in zero air and deliver four known concentrations in the range of atmospheric concentrations. Zeros and calibrations were carried out by delivering the gas mix to the top of the inlet housing so that the gases would interact with the inlet in exactly the same manner as during routine sampling and with sufficient flow to overflow the inlet during these diagnostics. Furthermore, standard additions were carried out by adding a small flow of the $\mathrm{NO}_{2}$ standard during sampling of the atmosphere to compare the instrument response and check for potential interferences resulting from atmospheric constituents. Due to the influence of water vapour on the fluorescence lifetime on $\mathrm{NO}_{2}$, a humidity correction was applied to the data. Based on laboratory tests, for every percent water vapour mixing ratio in the atmosphere, the data were corrected upward by $18 \%$. The magnitude of the correction was determined empirically for this specific instrument configuration and confirmed by standard additions because it depends on the details of the detection scheme and the use of a supersonic expansion. In previous configurations without a supersonic expansion (Thornton et al., 2000; Day et al., 2003) and in subsequent deployments with different pumping and detection schemes, the correction is less than $10 \%$ for every percent of water vapour.

The conversion of peroxy nitrates, alkyl nitrates and $\mathrm{HNO}_{3}$ to $\mathrm{NO}_{2}$ enables us to calibrate using only $\mathrm{NO}_{2}$ standards, however permeation tubes of n-propyl nitrate and $\mathrm{HNO}_{3}$ were also used to check instrument response and, most importantly, to confirm oven temperature settings. As a result of these diagnostic procedures, the concentrations measured by TD-LIF are accurate to better than $10 \%$ for $\mathrm{NO}_{2}$ and $15 \%$ for $\Sigma$ PNs, $\Sigma$ ANs, and $\mathrm{HNO}_{3}$. Because it was necessary to cycle through oven pairs, measurement intervals for any compound were roughly $30 \mathrm{~min}$, during which time data were collected at $1 \mathrm{~Hz}$.

Figure 2 shows data acquired while sampling the atmosphere and slowly ramping the hotter oven (Oven 1) from a setting above the cool oven (Oven 2) to the same temperature. The y-axis shows that the concentrations in both cells are on average the same when their oven temperatures are the same. The S-shape is consistent with the sample residence time in the oven and the known bond energies and unimolecular dissociation kinetics of the reactive nitrogen species being measured. The shapes of these atmospheric scans are consistent with those observed using a diffusion tube PAN standard and permeation tube standards of n-propyl nitrate and $\mathrm{HNO}_{3}$ added to both dry zero air and to ambient air, confirming that atmospheric constituents do not influence the decomposition behaviour of the nitrogen oxide species.

Because there is no particle filter on the inlets, aerosol that comprises volatile nitrates (i.e. $\mathrm{NH}_{4} \mathrm{NO}_{3}$ ) thermally decomposes in the ovens yielding $\mathrm{HNO}_{3}$, further decomposed to $\mathrm{NO}_{2}$ only in the $550^{\circ} \mathrm{C}$ oven. Therefore the values reported for the concentration of $\mathrm{HNO}_{3}$ represent the sum of gas phase and semi-volatile aerosol nitrate. Laboratory studies have confirmed that the measurement does not capture non-volatile aerosol nitrate salts (Bertram and Cohen, 2003). Similarly, we would expect any particulate organic nitrate to contribute to the measurements made following the $330^{\circ} \mathrm{C}$ oven. Very little is known about the abundance of particle phase organic nitrates in the atmosphere.

\section{Regional transport}

Due to its position on the western slope of the Sierra Nevada, Big Hill is subjected to extremely regular wind patterns, especially during the summer. Daytime heating causes upslope flow that draws air from California's Central Valley eastward into the higher elevations of the Sierra Nevada range. When the sun sets, the flow reverses and the air drains from higher elevations back toward the valley floor (Fig. 1). This flow regime persists along much of the western slope of the Sierra Nevada (Zhong et al., 2004) and strongly influences the seasonal and diurnal patterns observed in primary and 
secondary pollutants seen in the region (van Ooy and Carroll, 1995; Bytnerowicz et al., 2000; Carroll and Dixon, 2002).

Wind speed and direction measurements made at the UCBFRS, Big Hill, and other sites maintained by the California Air Resources Board in the vicinity show that the general wind direction in the region is from the WSW during the day and the east at night. The UC-BFRS tends to experience winds from the NE at night while flow at Big Hill is from the SE, likely due to topographical differences between the two sites. During upslope advection, the concentration of constituents within the urban plume may be altered by dilution, deposition, photochemical transformations and further emissions. Examining the measurements made at sites along the Sacramento - Lake Tahoe transect allows us to separate out these parameters and identify the variables controlling nitrogen oxide concentrations in the Sierra Nevada foothills downwind of Sacramento.

Observations made at these ground sites reflect the processing of boundary layer airmasses downwind of Sacramento during the daytime. Evidence that is described later shows that at $1860 \mathrm{~m}$ elevation, Big Hill frequently experiences nighttime downslope flow from the free troposphere. The boundary layer is expected to be surface-tracking, at least to elevations of $2000 \mathrm{~m}$ in the daytime, and is significantly shallower at night. Figure 3 shows a calculation of the net weekly east-west airflow averaged for the years 20012003 , based on wind speed and direction measurements at UC-BFRS. The data suggest the while net airflow between March and October is from west to east, during the winter months long periods of downslope flow result in the net direction of flow at the surface being from Lake Tahoe toward Sacramento. During the winter, daytime upslope flow is generally too short-lived to transport anthropogenic pollutants from the Central Valley significantly further east than Big Hill. Meteorological measurements made at the surface can not capture the effect of flow aloft, which may be particularly different during winter months when storm systems tend to move rapidly from west to east.

On an average midsummer day, an airmass moves roughly $100 \mathrm{~km}$ from east to west while the sun is up and then may backtrack $50 \mathrm{~km}$ to the west overnight when the flow is reversed. This pattern results in air sloshing back and forth along the western slopes of the Sierra and contributes to an increase in the regional background of reactive nitrogen. At lower elevation sites, like UC-BFRS, airmasses measured at night were likely also sampled several hours earlier when they passed by in the opposite direction. At Big Hill, meteorological and chemical observations during the early morning hours suggests that the site is experiencing descending air characteristic of the free troposphere. Because of the characteristic transport times in the region, derived from local wind speeds and directions, airmasses passing over Granite Bay between 06:00 and 12:00 PST represent the initial conditions of airmasses that reach the UC-BFRS and Big Hill between roughly 11:00 and 20:00.

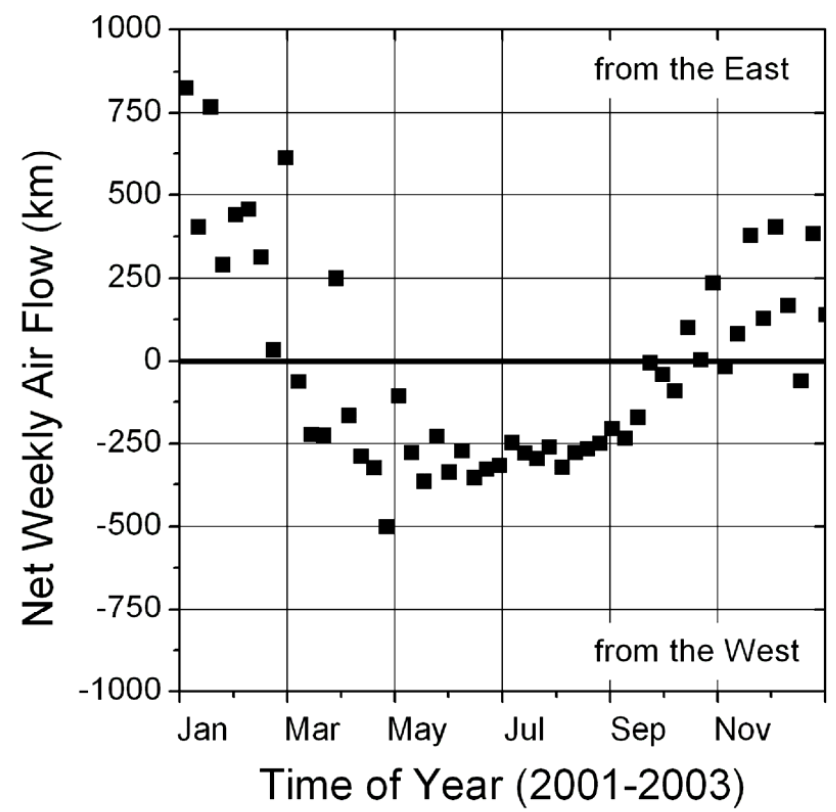

Fig. 3. Depiction of regional weekly net east-west airflow using meteorological data from UC-BFRS for the years 2001-2003. Between March and October, net flow in the region is from west to east, however this trend is reversed during the winter months.

\section{Results and analyses}

Measurements of $\mathrm{NO}_{2}$, total peroxy nitrates, total alkyl nitrates and $\mathrm{HNO}_{3}$ were made between March 2003 and February 2004 at Big Hill. Meteorological variables, ozone, and $\mathrm{PM}_{10}$ were also measured and are incorporated into the analysis. The corresponding measurements made at UC-BFRS are included to develop a more complete picture of the factors controlling the distribution of reactive nitrogen within the region. The annual cycle of measurements are discussed with reference to seasonal differences and their causes. Then the summertime data (June through October) are analyzed more fully to examine correlations between trace gas constituents and climate variables. Diurnal cycles from Big Hill, UC-BFRS, and Granite Bay are compared to derive an understanding about the relative roles of chemical production and loss, dilution and deposition in the urban plume.

\subsection{Seasonal cycles in nitrogen oxide species at Big Hill}

Data were obtained at Big Hill from March 2003February 2004. Because of electrical power failures virtually no data were collected during May 2003. The nearly complete annual cycle allow us to compare meteorology and reactive nitrogen throughout most of the year. Figure 4 presents annual observations of temperature, absolute water vapour, and total reactive nitrogen. For measurements at this remote site, we define $\mathrm{NO}_{\mathrm{y}}$ as the sum of all compounds measured by TD-LIF $\left(\equiv \mathrm{NO}_{2}+\Sigma \mathrm{PNs}+\Sigma \mathrm{ANs}+\mathrm{HNO}_{3}\right)$, as the 


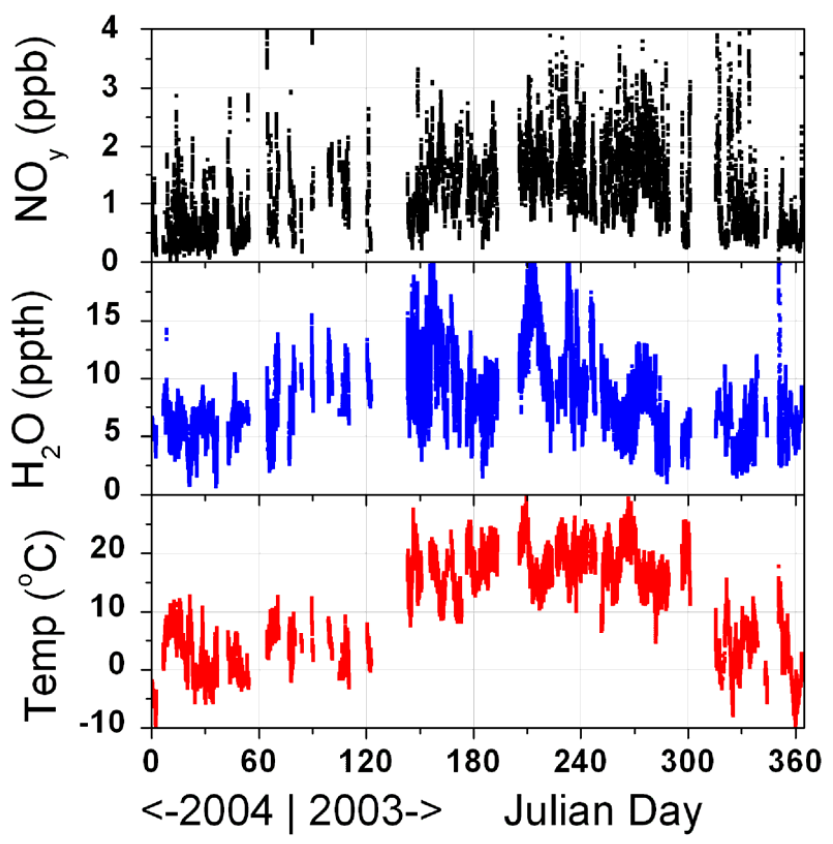

Fig. 4. Full dataset obtained at the Big Hill monitoring site for $\mathrm{NO}_{\mathrm{y}}$, absolute water in parts per thousand, and temperature. Data acquisition began 5 March 2003 (day 64) and ended on 23 February 2004 (day 54).

contribution from other species is expected to be less than $10 \%$ based on comparisons with a total $\mathrm{NO}_{\mathrm{y}}$ instrument made at UC-BFRS (Dillon, 2002). The water vapour value is reported as a mole fraction in parts per thousand (ppth). Based on the temperature data, it seems reasonable to consider two different sets of conditions: summer (June through October) and winter (November through April). While the relative humidity was quite low during the summer months, the absolute water vapour content is actually higher on average during summer compared to winter. Reactive nitrogen is higher during the summer months at the site though there is substantial day-to-day variability. Most notable perhaps is that the lower values, generally measured during the early morning, reach down almost to zero during the winter but generally not below $0.5 \mathrm{ppb}$ in the summer. This seasonal cycle is consistent with corresponding measurements carried out at the UC-BFRS from 2001-2005. While emissions of precursor $\mathrm{NO}_{\mathrm{x}}$ are not known to change substantially in the region by season, what does change is the extent to which these urban emissions are processed and transported to the western slope of the Sierra. As discussed above, net surface flow during the winter months is actually from east to west, so reactive nitrogen does not have the same opportunity to build up in the foothills and mountains that it does in the summer. The seasonal cycle in $\mathrm{NO}_{\mathrm{y}}$ at $\mathrm{Big} \mathrm{Hill}$ and the UC-BFRS is very different than that observed at sites that do not have a seasonal cycle in transport patterns. For example, Harvard Forest continues to sample air from urban

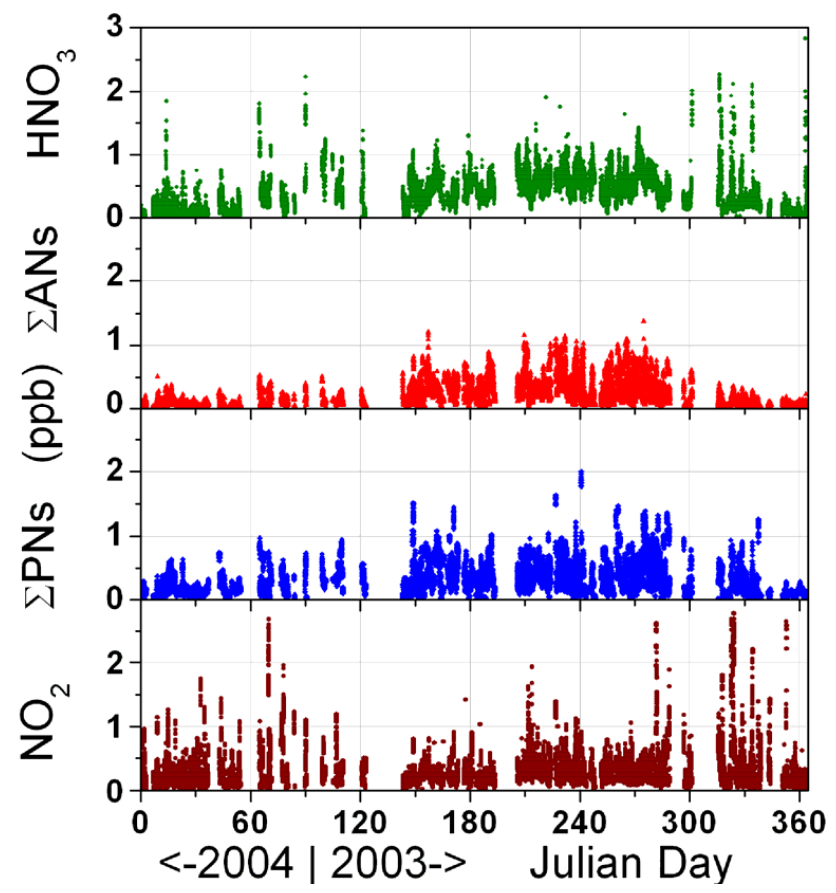

Fig. 5. Annual record of individual $\mathrm{NO}_{\mathrm{yi}}$ species, $\mathrm{NO}_{2}, \Sigma \mathrm{PNs}$, $\Sigma$ ANs and $\mathrm{HNO}_{3}$ measured at Big Hill. Data points represent a 3min average and all concentrations are reported in parts per billion by volume.

sources to a similar extent throughout the year. During winter, lower rates of oxidation reduce the conversion of $\mathrm{NO}_{2}$ to $\mathrm{HNO}_{3}$, the ultimate sink of $\mathrm{NO}_{\mathrm{y}}$, and therefore maximum $\mathrm{NO}_{\mathrm{y}}$ values are measured during the winter months (Moody et al., 1998; Munger et al., 1998). The shallower planetary boundary layer during the winter months also favors the accumulation of higher concentrations of pollutants. Another feature of the sites on the western slope of the Sierras that distinguish them from other locations with annual records is that because precipitation is rare in the western Sierra during the summer, wet deposition only acts as an important sink of $\mathrm{NO}_{\mathrm{y}}$ during the winter.

Figure 5 displays the full annual record for all the individual $\mathrm{NO}_{\mathrm{yi}}$ compounds at Big Hill. The organic nitrate species, $\Sigma$ ANs and $\Sigma$ PNs maximize during the summer months, when higher temperatures and photochemical activity result in increased precursor VOC emissions, more rapid photochemistry and more persistent transport. This pattern contrasts with seasonal observations of PAN at more remote locations such as northern Japan (Tanimoto et al., 2002) and northern Europe (Beine and Krognes, 2000), which exhibit springtime maxima and summertime minima. $\mathrm{HNO}_{3}$ is also generally higher during the summer months, averaging around $0.5 \mathrm{ppb}$, but higher excursions tend to occur during the winter months. $\mathrm{NO}_{2}$ has the weakest seasonal cycle, likely because of compensatory effects between transport and chemistry. During the hot summer months, strong transport 


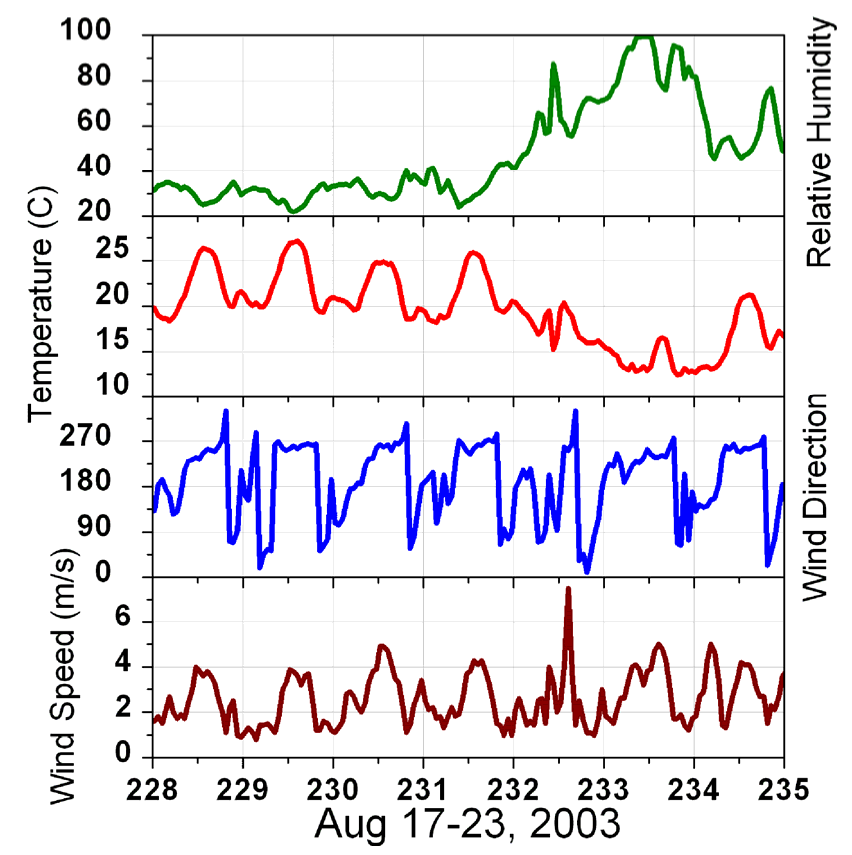

Fig. 6. Observations of relative humidity (\%), temperature $\left({ }^{\circ} \mathrm{C}\right)$, wind direction, and wind speed $(\mathrm{m} / \mathrm{s})$ from a typical summer week at Big Hill.

of urban emissions to remote high-elevation sites is offset by rapid photochemical oxidation of $\mathrm{NO}_{\mathrm{x}}$ to $\mathrm{NO}_{\mathrm{y}}$. In the winter, the plume has barely reached the site before downslope flow carries the urban influence away but a much greater fraction of the total $\mathrm{NO}_{\mathrm{y}}$ remains as $\mathrm{NO}_{2}$ due to reduced photochemistry.

Many of the winter season high $\mathrm{NO}_{\mathrm{y}}$ events, especially in November 2003, occurred during prescribed burning events carried out by the U.S. Forest Service or Sierra Pacific Industries, who own much of the nearby forests. Smoke plumes could also be seen from upwind apple orchards and vineyards. During these nearby burning events, $\mathrm{NO}_{2}$ and $\mathrm{HNO}_{3}$ were the most substantial contributions to $\mathrm{NO}_{\mathrm{y}}$ and particulate nitrate was likely an important constituent based on data from the BAM and two week samplers. Some of the low values of reactive nitrogen measured during the winter are the result of precipitation events that scrub soluble forms of $\mathrm{NO}_{y}$, such as $\mathrm{HNO}_{3}$, from the atmosphere.

\subsection{Summer and winter timelines at Big Hill}

In this section a summer week and a winter week are examined in more detail. Figure 6 shows meteorological data from a typical summer week that starts with hot dry conditions, with a cooler wetter weather pattern moving in on day 232 . The pattern of upslope-downslope flow is dominant on all days except the day of the weather shift. Daytime winds are close to $4 \mathrm{~m} / \mathrm{s}$, while at night wind speeds average around $1 \mathrm{~m} / \mathrm{s}$ and are more variable in direction.

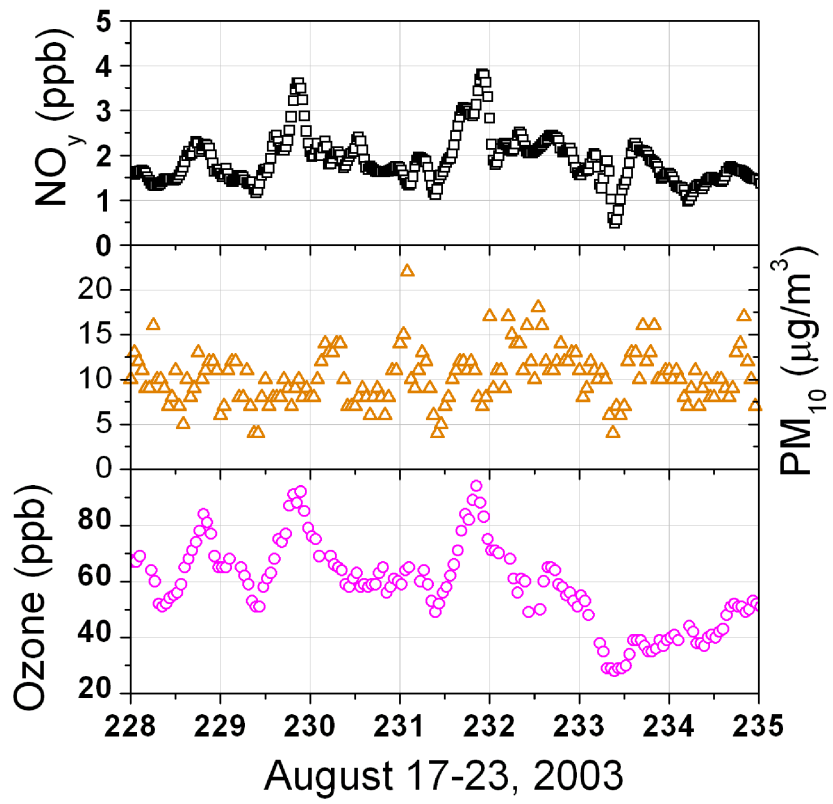

Fig. 7. Observations of $\mathrm{NO}_{\mathrm{y}}$ and $\mathrm{O}_{3}(\mathrm{ppb})$ and $\mathrm{PM}_{1} 0\left(\mu \mathrm{g} / \mathrm{m}^{3}\right)$ from a typical summer week at Big Hill.

Figures 7 and 8 show the observations of ozone, total $\mathrm{NO}_{\mathrm{y}}$, $\mathrm{PM}_{10}$ and the individual $\mathrm{NO}_{\mathrm{y}}$ species for the same time period. The late afternoon maximum observed for most species is consistent with transport of urban pollutants by daytime upslope flow along the western Sierra slopes. Interestingly, while $\mathrm{NO}_{2}$ and $\Sigma$ PNs exhibit the characteristic afternoon peak on day 230, it is noticeably absent in both $\mathrm{O}_{3}$ and in $\Sigma$ ANs, which are a co-product of ozone (Darnall et al., 1976). In general, the patterns of $\mathrm{NO}_{\mathrm{y}}$ and $\mathrm{O}_{3}$ track each other during the summer months. However, an exception is that total $\mathrm{NO}_{\mathrm{y}}$ values do not decrease significantly at the end of the week, yet ozone is close to $30 \mathrm{ppb}$, and there is little apparent photochemical production.

Figure 9 shows the same meteorological variables as Fig. 6, but for a week in late November. Winter conditions are less consistent than during the summer, but this data demonstrate some widespread features of winter observations at Big Hill. The weather is cooler and the relative humidity is higher during this time period than in the summer. Several days of strong flow from the southwest are interrupted on day 324 with a return to the more common upslope-downslope pattern but with weaker winds. Figure 10 shows that the diurnal variability of ozone has diminished significantly compared to summer and values for the week all lie between 45 and 65 ppb. Ozone during this period is not correlated with $\mathrm{NO}_{\mathrm{y}}$, likely because $\mathrm{NO}_{\mathrm{y}}$ is influenced by burning events during days 322-324. Figure 11 shows that strong flow from the west delivered high concentrations of $\mathrm{NO}_{2}, \mathrm{HNO}_{3}$ (and likely particulate nitrate) to the Big Hill site, probably due to plumes from upwind burning events. At the end of the weeklong period, a diurnal cycle in $\mathrm{NO}_{2}$, 


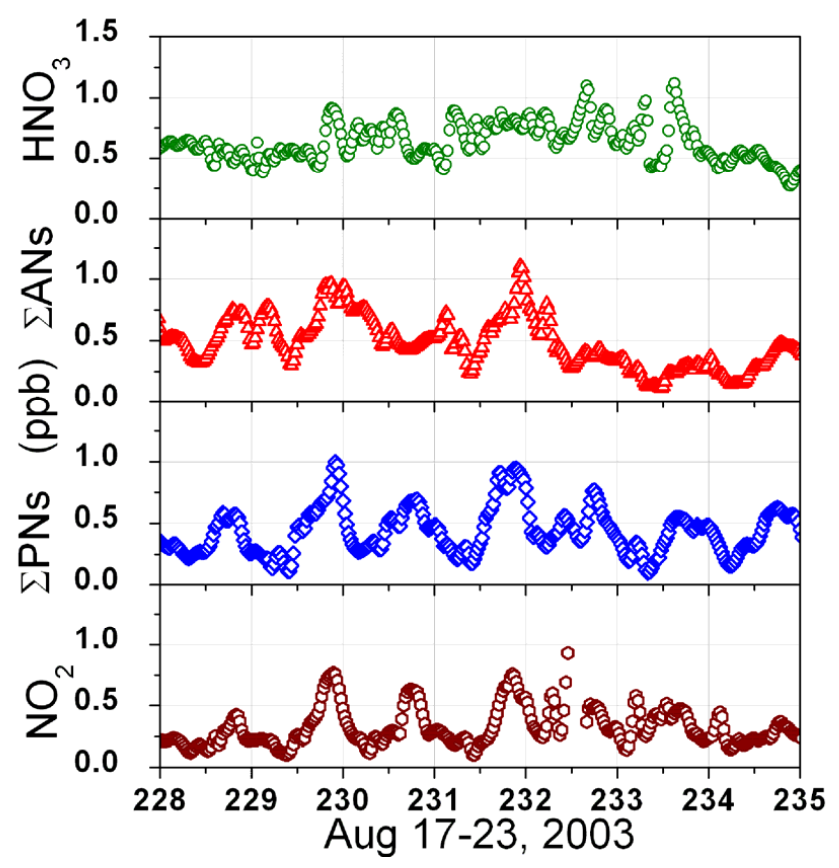

Fig. 8. Observations of $\mathrm{NO}_{2}, \Sigma \mathrm{PNs}, \Sigma \mathrm{ANs}$ and $\mathrm{HNO}_{3}$ from a typical summer week at Big Hill.

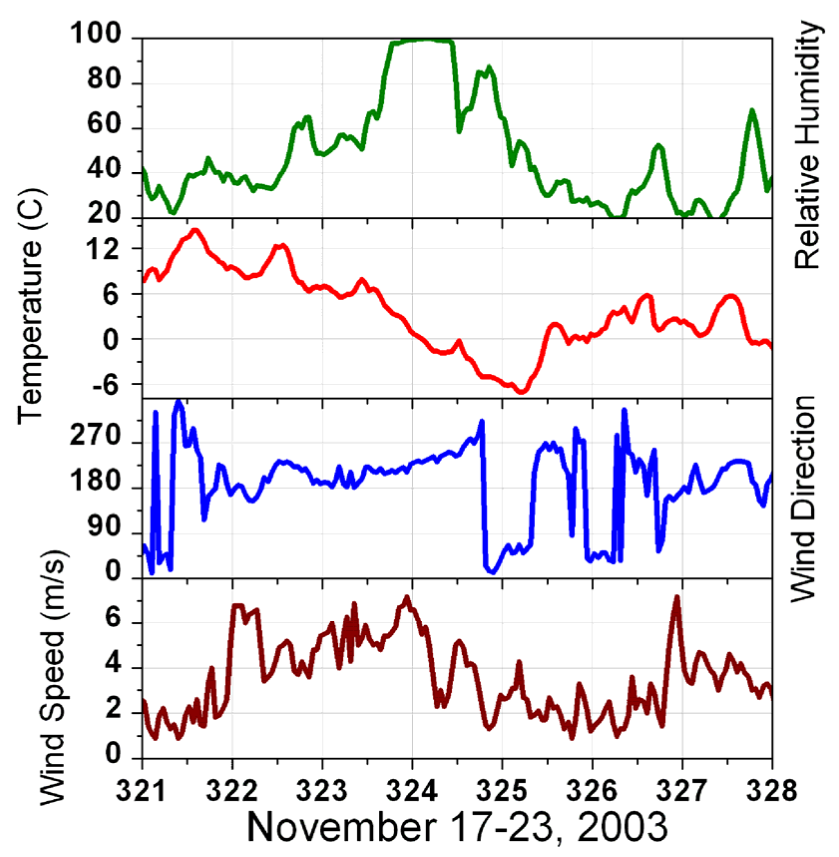

Fig. 9. Observations of relative humidity $(\%)$, temperature $\left({ }^{\circ} \mathrm{C}\right)$, wind direction, and wind speed $(\mathrm{m} / \mathrm{s})$ from a typical winter week at Big Hill.

and especially $\Sigma$ PNs can be seen with the return to the usual flow pattern. Just as ozone concentrations have ceased to rise significantly above background values in the region, $\Sigma$ ANs remains very low throughout most of the winter.

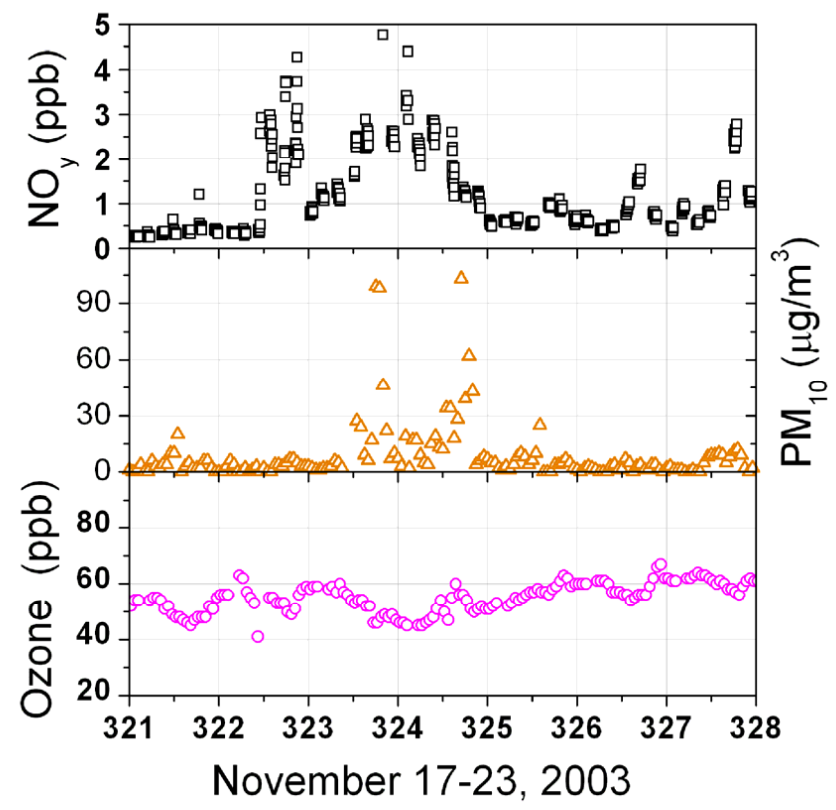

Fig. 10. Observations of $\mathrm{NO}_{\mathrm{y}}$ and $\mathrm{O}_{3}(\mathrm{ppb})$ and $\mathrm{PM} 10\left(\mu \mathrm{g} / \mathrm{m}^{3}\right)$ from a typical winter week at Big Hill.

\subsection{Summer diurnal profiles of meteorology, trace gases and particles}

Figure 12 demonstrates the remarkably consistent meteorology experienced by the Big Hill site during the summer months (defined as June through October in this analysis). Temperatures were between 10 and $30^{\circ} \mathrm{C}$, with an average swing of approximately $7^{\circ} \mathrm{C}$ between night and day. Rain was extremely rare and the relative humidity was generally between 25 and $50 \%$. With the exception of very few days, between roughly 09:00 and 20:00, the wind blows from the west. Wind direction during the night is more variable but is generally from the east or southeast. Wind speed maximizes during the afternoon at about $4 \mathrm{~m} / \mathrm{s}$, and is slowest in the early evening when the predominant flow is changing direction from upslope to downslope. Wind speeds during the night are more variable but are generally slower than during the day. We exploit the consistency of the transport and climate variables to analyze the data statistically without any prior meteorological filtering and to develop our understanding of the important parameters involved in determining $\mathrm{NO}_{\mathrm{y}}$ distribution in the region.

Figure 13 depicts the diurnal cycles of ozone, particulate matter, and total reactive nitrogen at Big Hill. As a result of daytime flow from the Sacramento Valley toward the site, and the photochemical processing that occurs along the way, all three of these variables maximize around 18:00-20:00, just before downslope flow begins. The minimum values in each of the variables occur around 10:00 just after upslope flow begins. The summertime diurnal cycles in the individual reactive nitrogen species are shown in Fig. 14. To gain 


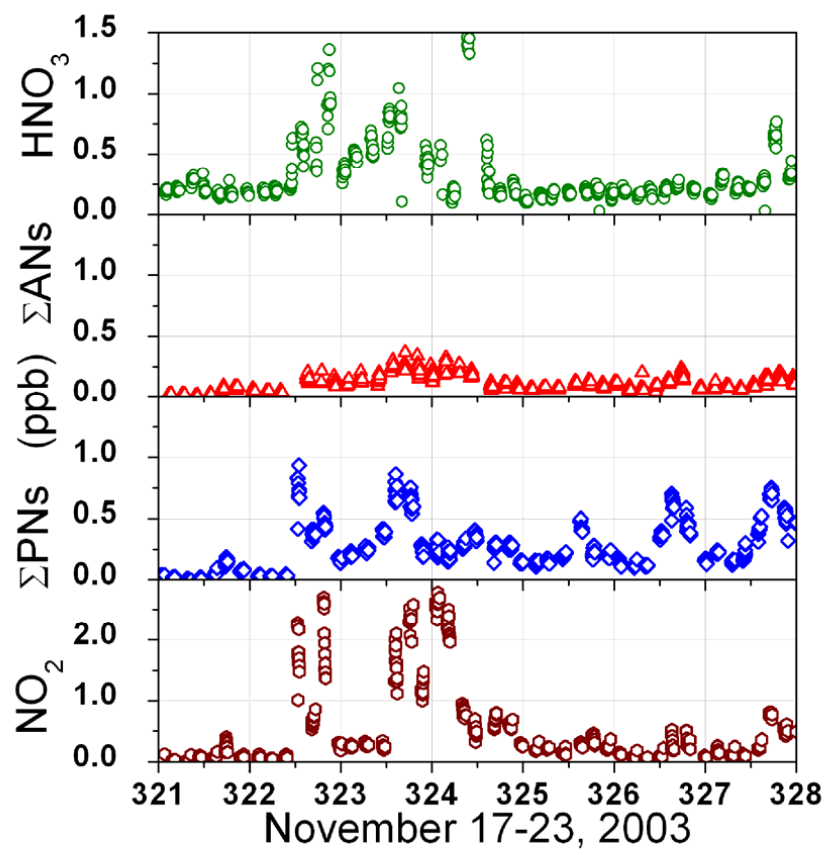

Fig. 11. Observations of $\mathrm{NO}_{2}, \Sigma \mathrm{PNs}, \Sigma \mathrm{ANs}$ and $\mathrm{HNO}_{3}$ from a typical winter week at Big Hill. Note different axes on $\mathrm{NO}_{2}$ panel.

further perspective on the factors controlling the distribution of reactive nitrogen and ozone along the western slope of the Sierras, a comparison can be made between observations at Granite Bay, UC-BFRS, and Big Hill. The diurnal profiles in Fig. 15 are restricted to data acquired during the months of July through September at all sites, because of the more limited temporal coverage of the Granite Bay data set. For $\mathrm{NO}_{2}$, $\mathrm{HNO}_{3}$, and $\mathrm{NO}_{\mathrm{y}}$, measurements from Granite Bay have been divided by three to put them on the same scale as the remote sites. In contrast concentrations of organic nitrates at all three sites are approximately in the same range. While the sum of species measured by TD-LIF adequately represents $\mathrm{NO}_{\mathrm{y}}$ at remote sites like Big Hill and UC-BFRS, NO is a significant fraction of daytime reactive nitrogen at Granite Bay and has been estimated using chemical and meteorological factors (Cleary et al., 2005) for Fig. 15.

Mobile emissions are the main source of nitrogen oxides in the Sacramento Valley, thus concentrations of $\mathrm{NO}_{\mathrm{y}}$ increase substantially during morning rush hour, often exceeding $10 \mathrm{ppb}$ at Granite Bay (Fig. 15a). The increase in $\mathrm{NO}_{\mathrm{y}}$ shortly before noon at the remote sites is consistent with a 5$6 \mathrm{~h}$ upslope transit time of the urban emissions. $\mathrm{NO}_{\mathrm{y}}$ is better conserved than any of the individual constituent species and is mainly lost to deposition and dilution. At UC-BFRS, $\mathrm{NO}_{\mathrm{y}}$ peaks between 15:00 and 18:00 with concentrations roughly one quarter of the $\mathrm{NO}_{\mathrm{y}}$ leaving Granite Bay five hours earlier. At Big Hill, peak $\mathrm{NO}_{\mathrm{y}}$ concentrations occur between 16:00 and 19:00 and have been reduced further to roughly one fifth of the initial concentrations in the plume when it

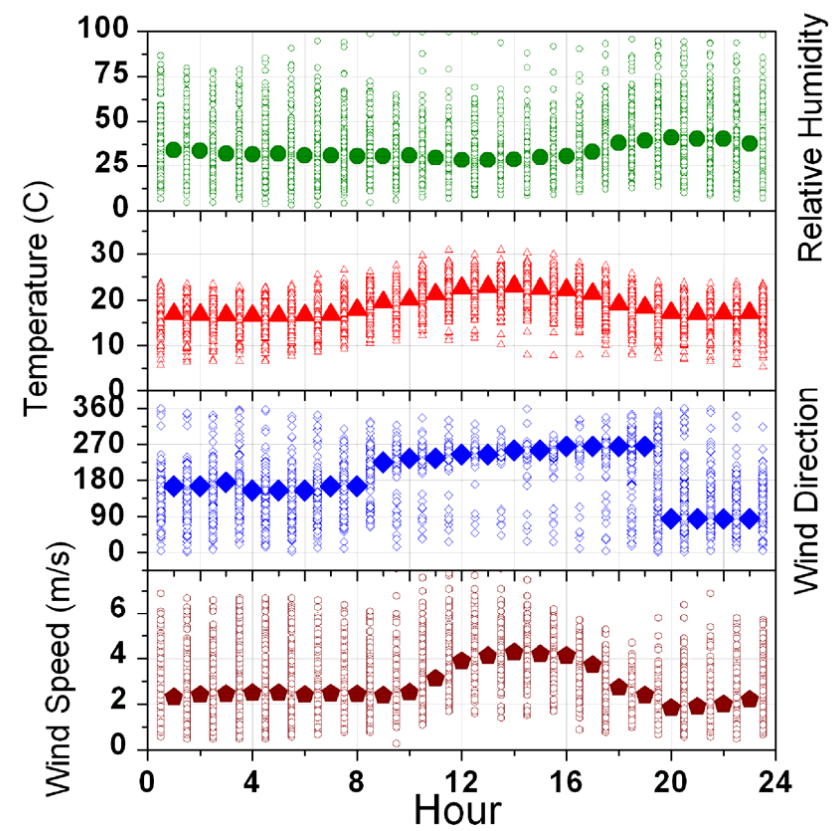

Fig. 12. Observations of relative humidity $(\%)$, temperature $\left({ }^{\circ} \mathrm{C}\right)$, wind direction, and wind speed $(\mathrm{m} / \mathrm{s})$ by hour of day for the entire summer (June through October) at Big Hill. Individual hourly data points for each day (open symbols) are overlaid by the averages (mode for wind direction and mean for other variables) for each hour (solid symbols).

left Sacramento. Emissions during the evening rush hour do not have time to travel far upslope before the sun sets and the flow reverses, preventing these emissions from moving upslope. The small early morning rise in $\mathrm{NO}_{\mathrm{y}}$ and its constituent species at UC-BFRS has been interpreted to result from the break up of the morning boundary layer, allowing air that has not been subjected to surface losses mix down from above (Day, 2003).

In contrast to $\mathrm{NO}_{\mathrm{y}}$, which is a tracer both of primary urban emission and their secondary photochemical products, ozone is solely a secondary pollutant. For Granite Bay, odd oxygen $\left(\mathrm{O}_{\mathrm{x}} \equiv \mathrm{O}_{3}+\mathrm{NO}_{2}\right)$ is plotted to account for the effect of recent $\mathrm{NO}_{\mathrm{x}}$ emissions on the conversion of ozone (Fig. 15b). At the remote sites, recent $\mathrm{NO}_{\mathrm{x}}$ emissions are not important and $\mathrm{NO}_{2}$ accounts for less than $3 \%$ of odd oxygen and ozone is plotted alone. At Granite Bay, the $\mathrm{O}_{\mathrm{x}}$ profile reflects rapid photochemical production of ozone in the urban and suburban environment. Ozone produced in Sacramento is advected upslope, and ozone production also continues during transit. Ozone is lost through deposition and dilution, though the regional background is not sufficiently low to make dilution a rapid sink. The dip in ozone between 06:00 and 09:00 at UC-BFRS is associated with the opening of plant stomata coincident with sunrise (Kurpius and Goldstein, 2003). This feature is not observable at Big Hill, likely due to the lack of local vegetation. During upslope flow, Big Hill consistently 


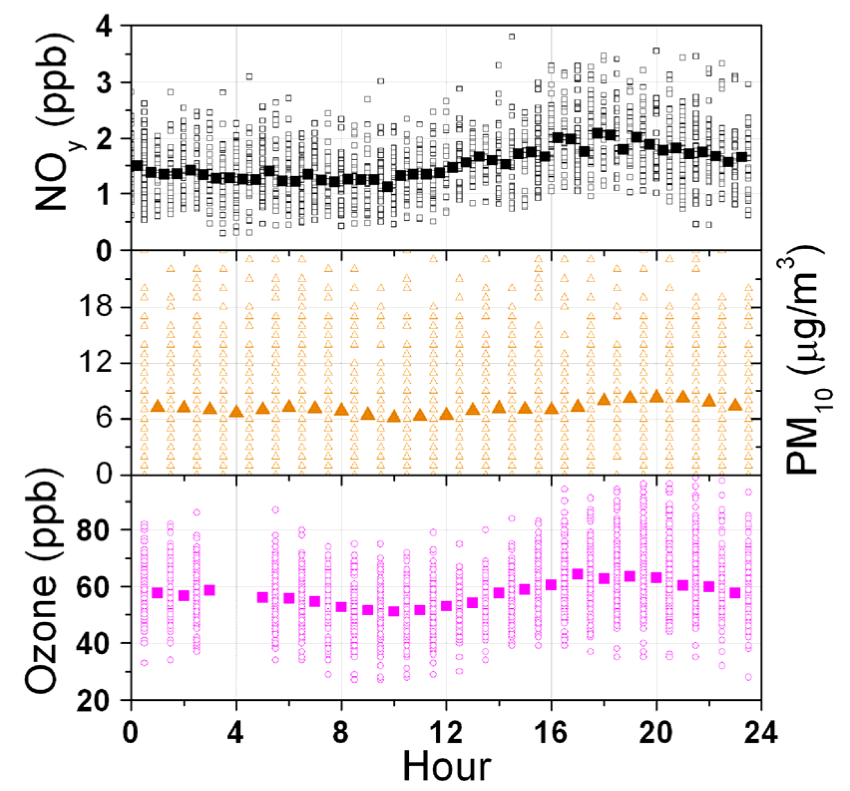

Fig. 13. Diurnal profile of summertime observations of $\mathrm{NO}_{\mathrm{y}}$ and $\mathrm{O}_{3}(\mathrm{ppb})$ and $\mathrm{PM}_{10}\left(\mu \mathrm{g} / \mathrm{m}^{3}\right)$ at Big Hill. Individual measurements (open shapes) of $\mathrm{O}_{3}$ and $\mathrm{PM}_{10}$ were made every hour at Big Hill, and the $\mathrm{NO}_{\mathrm{y}}$ data have been averaged to half hour points. The average value for every hour or half hour is overlaid in the solid points.

has less ozone than UC-BFRS, however during periods of downslope flow, $\mathrm{O}_{3}$ concentrations are higher at Big Hill. This may reflect the fact that nighttime chemical and deposition losses for $\mathrm{O}_{3}$ are less efficient at the higher elevation, exposed site.

$\mathrm{HNO}_{3}$ has a remarkably flat diurnal profile at the Big Hill site, in contrast to measurements made by TD-LIF at both the UC-BFRS and Granite Bay, a Sacramento suburb (Fig. 15c). At those sites, the profile of $\mathrm{HNO}_{3}$ followed that of the sun, peaking in the middle of the day and staying relatively flat at low concentrations during the night. During the day, $\mathrm{HNO}_{3}$ at Big Hill is lower because the site is further from the $\mathrm{NO}_{\mathrm{x}}$ source and the $\mathrm{HNO}_{3}$ produced during plume transit has had more time to deposit. The continuing loss of $\mathrm{NO}_{2}$ in the daytime plume as it moves eastward likely results in lower $\mathrm{OH}$ in remote regions, reducing the local production rate of $\mathrm{HNO}_{3}$ considerably near Big Hill. The deposition rate of $\mathrm{HNO}_{3}$ is rapid ( $\sim$ hours), so in the absence of production, $\mathrm{HNO}_{3}$ in an airmass in constant contact with the surface would be expected to go to zero during the night. The photochemical production of nitric acid does not occur at night, however $\mathrm{NO}_{3}$ chemistry and heterogeneous $\mathrm{N}_{2} \mathrm{O}_{5}$ chemistry can act as a nighttime source (Geyer et al., 2001; Brown et al., 2006). The heterogeneous production of $\mathrm{HNO}_{3}$ is quadratic in $\mathrm{NO}_{2}$, is favoured by high aerosol surface area, and competes with $\mathrm{NO}_{3}$ reactions with VOC. Wintertime measurements in the San Francisco Bay Area suggested that under cool, humid conditions the conversion of $\mathrm{NO}_{\mathrm{x}}$ to $\mathrm{HNO}_{3}$ can be equally or

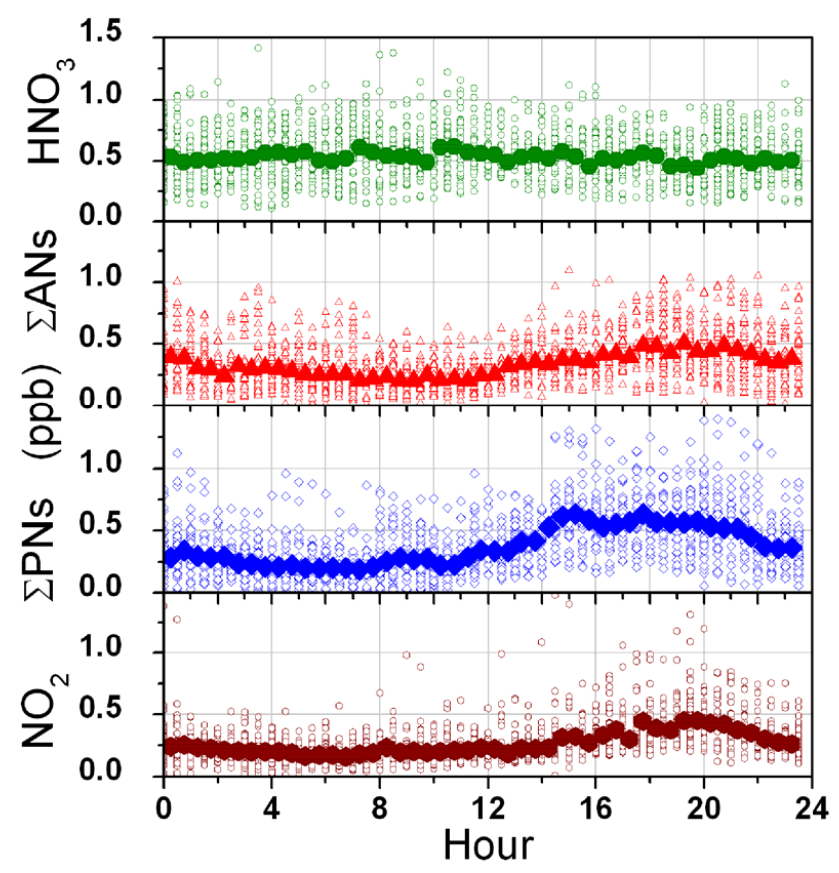

Fig. 14. Diurnal profile of summertime observations of $\mathrm{NO}_{2}$, $\Sigma$ PNs, $\Sigma$ ANs and $\mathrm{HNO}_{3}$ at Big Hill. Individual half hour data points for each day (open symbols) are overlaid by the averages for each half hour (solid symbols).

more efficient at night than reactions with $\mathrm{OH}$ during the day (Wood et al., 2005). The plateau in $\mathrm{HNO}_{3}$ concentrations overnight at Granite Bay suggest that nighttime production may be occurring, but this could only be quantified with further information about aerosol surface area and VOC reactivity toward $\mathrm{NO}_{3}$. At the remote sites, significantly lower concentrations of $\mathrm{NO}_{2}$ discourage $\mathrm{N}_{2} \mathrm{O}_{5}$ production, but again aerosol surface area and VOC reactivity need to be known to quantify possible production rates.

An alternative explanation for the non-zero concentrations of $\mathrm{HNO}_{3}$ at these remote surface sites is the mixing down of airmasses that have not been recently near the surface. At Big Hill, the water vapour mixing ratio frequently decreases abruptly shortly after midnight, suggesting that the site is experiencing mixing from above of drier airmasses that have less total $\mathrm{NO}_{\mathrm{y}}$ but of which $\mathrm{HNO}_{3}$ is a relatively important constituent. Because of the high elevation at Big Hill, the site appears to sample descending air characteristic of the free troposphere, in which the $\mathrm{HNO}_{3}$ formed has not had the opportunity to deposit. An illustration of this effect can be found in Fig. 16, a time series of absolute water concentration and the ratio of $\mathrm{HNO}_{3} / \mathrm{NO}_{\mathrm{y}}$ observed at Big Hill. Observations of relatively high nighttime $\mathrm{HNO}_{3}$ at remote sites likely reflect the presence of descending airmasses rather than a significant heterogeneous source.

Alkyl nitrates are formed photochemically through the association of peroxy radicals with nitric oxide. During the 

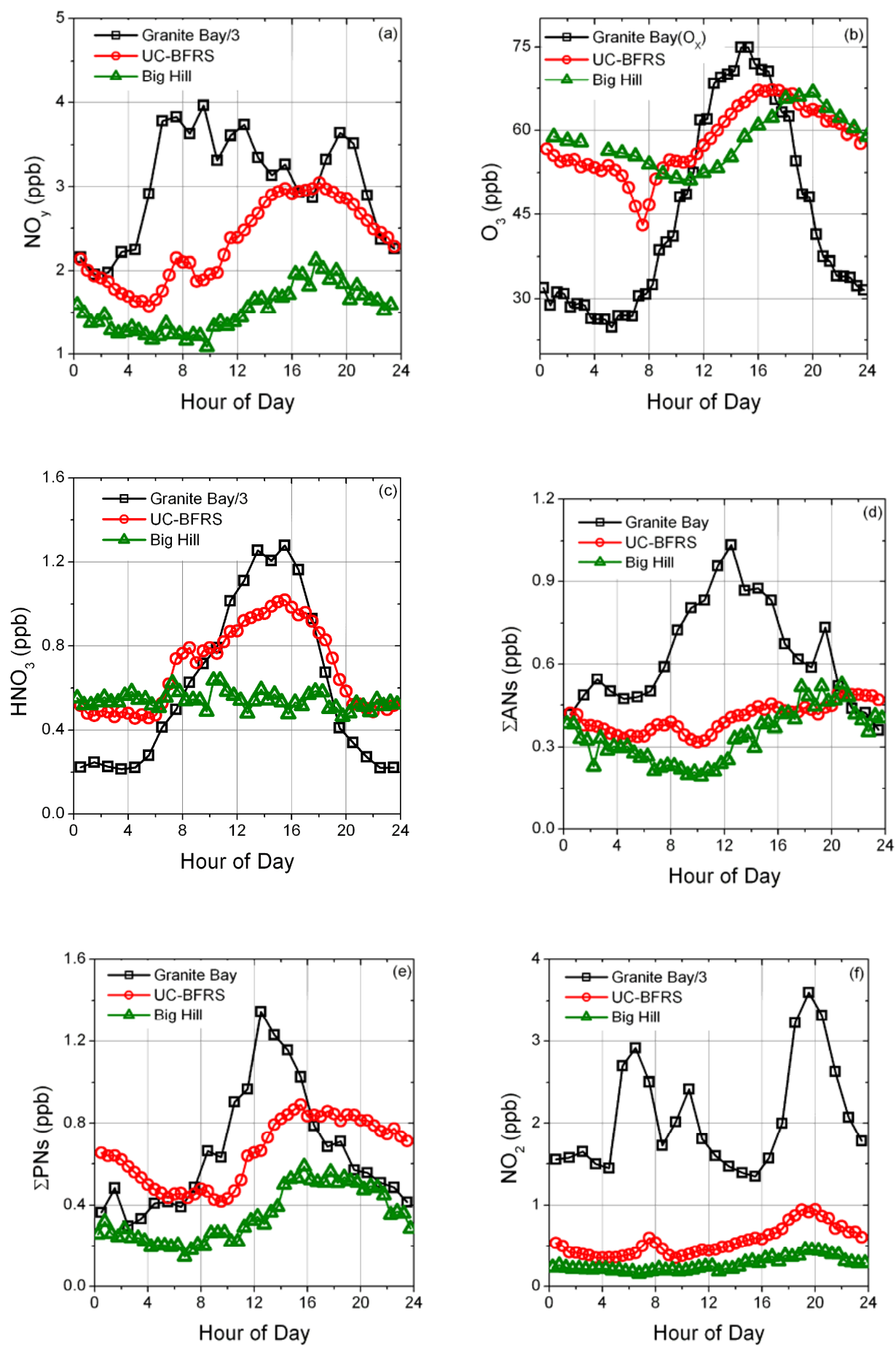

Fig. 15. Diurnal trends in reactive nitrogen species and ozone at three sites along the Sacramento urban plume. Because Granite Bay measurements were made in the months of July-September, observations from Big Hill and the UC-BFRS are limited to those months also.

night they may also be produced by the oxidation of unsaturated VOC by the $\mathrm{NO}_{3}$ radical. The $\mathrm{RO}_{2}+\mathrm{NO}$ reaction also forms ozone, hence alkyl nitrate concentrations are generally a good indication of ozone production. Alkyl nitrates have also been observed to be correlated with carbon monoxide at remote sites (Flocke et al., 1991; Shepson et al., 1993) however the CO monitor at Big Hill did not have sufficient sensitivity to make measurements during the campaign. In Granite 


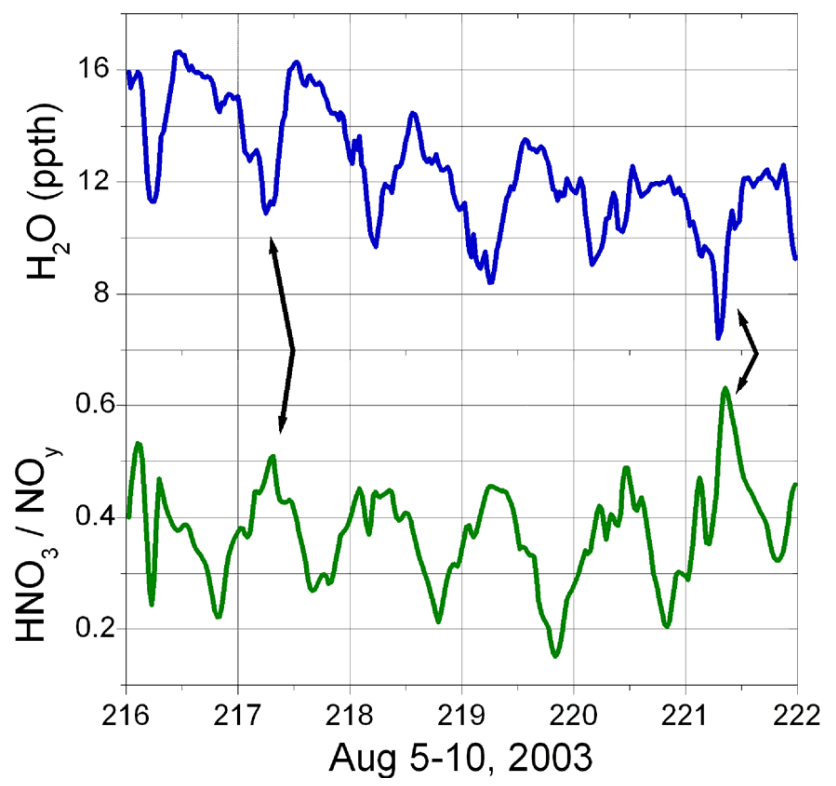

Fig. 16. Time series of absolute water vapour (upper panel) and the fraction of total reactive nitrogen that is nitric acid (lower panel). Arrows indicate two of the periods when sharp decreases in water are associated with an increasing importance of nitric acid in the reactive nitrogen budget.

Bay, $\Sigma$ ANs rise quickly in the morning and then remain relatively constant throughout the afternoon (Fig. 15d). At the remote sites, alkyl nitrates are at a minimum in the early morning and exhibit peak values in the late afternoon. $\Sigma$ ANs are a significant constituent of $\mathrm{NO}_{\mathrm{y}}$ in the Sacramento plume at these downwind locations, while nighttime measurements at Big Hill suggest that the airmasses characteristic of the free troposphere contain relatively low concentrations of $\Sigma$ ANs. TD-LIF observations of $\Sigma$ ANs at these sites are substantially larger than those reported by researchers measuring individual alkyl nitrates by GC-MS (Day et al., 2003; Cleary et al., 2005). Because the TD-LIF technique takes advantage of the characteristic bond energies of organic nitrates, it does not require prior identification of specific organic groups and the measurement represents the sum of all $\mathrm{RO}_{\mathrm{x}} \mathrm{NO}_{2}$ compounds in the atmosphere. The speciation of the alkyl nitrates observed at Big Hill is unclear, though the dominance of VOC reactivity by isoprene between Sacramento and Big Hill suggests that alkyl nitrates derived from isoprene products are likely important. The sinks of complex alkyl nitrates are poorly understood, though their thermal decomposition and photolysis lifetimes exceed several days. The presence of hydroxy-groups or unsaturated bonds in the organic chain may reduce the lifetime of a specific compound (e.g. Giacopelli et al., 2005, and references therein), though if it reacts to form a different alkyl nitrate, it will not register as a loss of $\Sigma$ ANs as seen by the TD-LIF measurements. Measurements in the western Sierra region suggest that $\Sigma$ ANs are a sig-

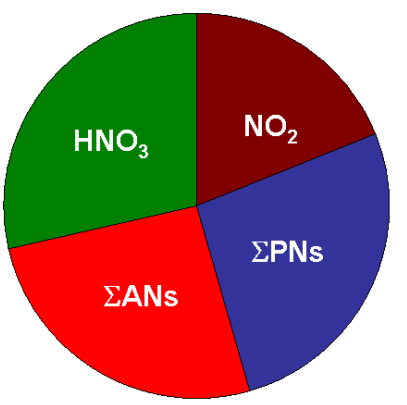

(a) $\mathrm{T}_{\max }>21^{\circ} \mathrm{C}$

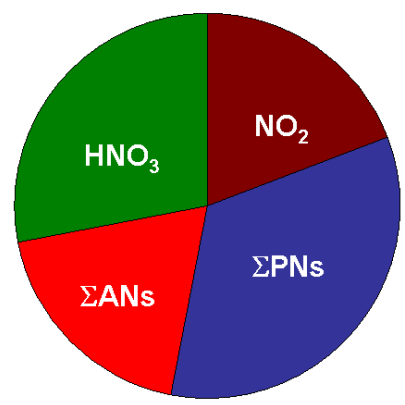

(b) $\mathrm{T}_{\max }<21^{\circ} \mathrm{C}$
Fig. 17. Distribution of $\mathrm{NO}_{\mathrm{y}}$ during daytime upslope flow at Big Hill. The data were separated by temperature such that chart (a) includes data from days on which the daytime maximum temperature at the site exceeds $21^{\circ} \mathrm{C}$, while chart (b) shows data from cooler days on which the temperature was never higher than $21^{\circ} \mathrm{C}$.

nificant fraction of $\mathrm{NO}_{\mathrm{y}}$ and that they tend to be long-lived, suggesting that they contribute substantially to the reactive nitrogen that is exported from the region and mixed into the free troposphere. The ability of alkyl nitrates to deposit to surfaces and contribute to nitrogen deposition is poorly understood.

$\Sigma$ PNs are formed through the association of a peroxy radical and nitrogen dioxide, but only those derived from acyl peroxy radicals are stable enough to survive in the lower atmosphere. The most common peroxy nitrate, peroxy acetyl nitrate (PAN), is the result of the photochemical oxidation of oxygenates in the presence of $\mathrm{NO}_{\mathrm{x}}$. Acyl peroxy nitrates act as a thermally labile reservoir for both $\mathrm{RO}_{2}$ and $\mathrm{NO}_{2}$ radicals and therefore on cooler days can sequester these radicals and reduce photochemical ozone production. Peroxy nitrates can also transport reactive nitrogen far from its original source, and act as radical sources upon subsequent decomposition (Singh, 1987). Organic nitrates have relatively low water solubility and their contribution to reactive nitrogen deposition is not well understood. In Granite Bay, the diurnal profile of $\Sigma$ PNs reflects rapid production and an approach to the photostationary state between these reservoir species and their radical precursors (Fig. 15e). The diurnal profiles at UC-BFRS and Big Hill are very similar, broadly peaking between 14:00 and 22:00 at values more than double those observed during early morning hours. While absolute concentrations of $\Sigma$ PNs are consistently lower at Big Hill than at UC-BFRS, there is more $\Sigma$ PNs per unit of precursor $\mathrm{NO}_{2}$ at the more remote site. The equilibrium between radicals and $\Sigma$ PNs is extremely temperature dependent and likely the temperatures experienced by the average airmass reaching Big Hill are colder, pushing a greater fraction of the precursor into the reservoir form.

Figure $15 \mathrm{f}$ shows that nitrogen dioxide is strongly influenced by local traffic patterns at Granite Bay. At the remote 
sites, $\mathrm{NO}_{2}$ has a strong diurnal cycle and has the latest peak of all of the reactive nitrogen compounds. The delayed timing of the peak concentrations can be explained by a combination of transport and photochemistry. The $\mathrm{NO}_{2}$ emitted into the plume takes around $6 \mathrm{~h}$ to arrive at the UC-BFRS and Big Hill sites. Air masses leaving Sacramento in the late morning are advected up the Sierra when photochemical activity is peaking, and the conversion of $\mathrm{NO}_{\mathrm{x}}$ to higher $\mathrm{NO}_{\mathrm{y}}$ species is maximized. Air leaving Sacramento in the afternoon and arriving at the remote sites in the early evening experiences lower levels of actinic radiation and therefore the later part of the plume has a larger fraction of $\mathrm{NO}_{2}$ remaining. Peak concentrations in the plume are roughly double the early morning minimum values.

5.4 Summertime distribution of reactive nitrogen and correlation with other variables

Changes in climate can be expected to drive differences in both transport and chemistry, affecting the geographical and temporal extent to which the urban plume influences remote sites, and the chemical partitioning with the plume. One of the most important climate variables that governs the distribution of reactive nitrogen oxides is temperature. The Big Hill summertime data were divided into two sets of days, half of which had a maximum daytime temperature above $21^{\circ} \mathrm{C}$ and half of which did not. The average amount of $\mathrm{NO}_{\mathrm{y}}$ in the plume (13:00-20:00) was 1.71 $\pm 0.04 \mathrm{ppb}$ (twice the standard deviation of the mean) on cold days and $1.91 \pm 0.04 \mathrm{ppb}$ on hot days, suggesting that higher local temperatures may indicate a slightly stronger transport efficiency of the plume, a longer photochemical lifetime of $\mathrm{NO}_{\mathrm{y}}$ in the plume, or increased emissions, possibly from soil. The partitioning of reactive nitrogen among its constituent species is strongly influenced by temperature as shown in Fig. 17. The left panel shows the partitioning among $\mathrm{NO}_{\mathrm{y}}$ species arriving at the site between 13:00-20:00 on days when the maximum temperature exceeded $21^{\circ} \mathrm{C}$. Comparison with cooler temperature data displayed in the right panel shows that while $\mathrm{NO}_{2}$ has undergone similar amounts of photochemical processing under both sets of conditions, lower temperatures favour the accumulation of peroxy nitrates over the production of alkyl nitrates. Peroxy nitrates account for over one third of the reactive nitrogen at the cooler temperatures, sequestering a substantial amount of reactive nitrogen in this reservoir. The reduced contribution of alkyl nitrates at lower temperatures is consistent with fewer $\mathrm{RO}_{2}$ and $\mathrm{NO}_{\mathrm{x}}$ radicals available to react to form ozone. Indeed, the mean ozone in the plume on the hot days is $64 \mathrm{ppb}$, while on cool days it is $58 \mathrm{ppb}$. Another facet of the temperature effect may be the increased emissions of many biogenic VOC at higher temperatures. A shift in the hydrocarbon composition toward longer chain compounds as opposed to carbonyl compounds could favour the production of alkyl nitrates over peroxy nitrates.
The correlation between total reactive nitrogen and the mole fraction of water is strong at Big Hill, as suggested by Fig. 16. The relationship between $\mathrm{H}_{2} \mathrm{O}$ and $\mathrm{NO}_{\mathrm{y}}$ is not as clear at the UC-BFRS, where it is likely that the transpiration of nearby vegetation has a strong influence on the water budget at the site. In contrast, water vapour appears to be a good indicator of transport of polluted airmasses at a high elevation site such as Big Hill. This is consistent with numerical simulations (Kimura and Kuwagata, 1995) and observations (Ohtani, 2001) in other areas that show thermally induced local circulations that transport water vapour from low elevations to mountainous areas. The absolute humidity of the airmass records the degree of mixing that the relatively moist, polluted urban plume has undergone in transit to the high elevation site. Observations during the night at Big Hill show that the air descending from the free troposphere tends to be much drier and have reduced total reactive nitrogen.

The implication is that nighttime observations at Big Hill allow us to occasionally sample airmasses that have not had recent contact with the surface. These airmasses may have traveled above the boundary layer during the daytime and have subsequently descended to the surface to undergo downslope transport at night. These airmasses have lower concentrations of $\mathrm{H}_{2} \mathrm{O}$ and $\mathrm{NO}_{\mathrm{y}}$ than those that are observed during upslope flow and their concentrations likely reflect the degree to which earlier surface emissions have mixed with cleaner air from the free troposphere. While the fractional contribution of $\mathrm{HNO}_{3}$ to $\mathrm{NO}_{\mathrm{y}}$ was higher in these nighttime airmasses, the absolute concentration of $\mathrm{HNO}_{3}$ was no higher than in the daytime plumes.

Figure 18 depicts the strong correlation between reactive nitrogen and ozone at the Big Hill monitoring site throughout the summer. Observations made during afternoon upslope flow are highlighted, however the urban plume still appears to influence the site with higher values for ozone and $\mathrm{NO}_{\mathrm{y}}$ during the night. Many of these high nighttime values are measured shortly after the wind has shifted direction and the air passing back by the site is still characteristic of plume air. The relationship between $\mathrm{NO}_{\mathrm{y}}$ and ozone is expected because both are derived from precursor emissions of nitrogen oxides. While in urban areas with high $\mathrm{NO}_{\mathrm{x}}$ concentrations, ozone can be negatively correlated with $\mathrm{NO}_{\mathrm{x}}$, in remote areas like Big Hill we expected ozone production to be limited by the availability of nitrogen oxides. Minimum values of $\mathrm{NO}_{\mathrm{y}}$ $(<1 \mathrm{ppb})$, which occur in the early morning hours, are associated with ozone levels between 35 and $60 \mathrm{ppb}$, while maximum values of $\mathrm{NO}_{\mathrm{y}}(>2.5 \mathrm{ppb})$ are associated with ozone between 65 and $95 \mathrm{ppb}$. Clearly the chemistry and transport patterns responsible for transforming nitrogen oxides and transporting them along the western slope of the Sierra Nevada have similar effects for ozone and total reactive nitrogen. 


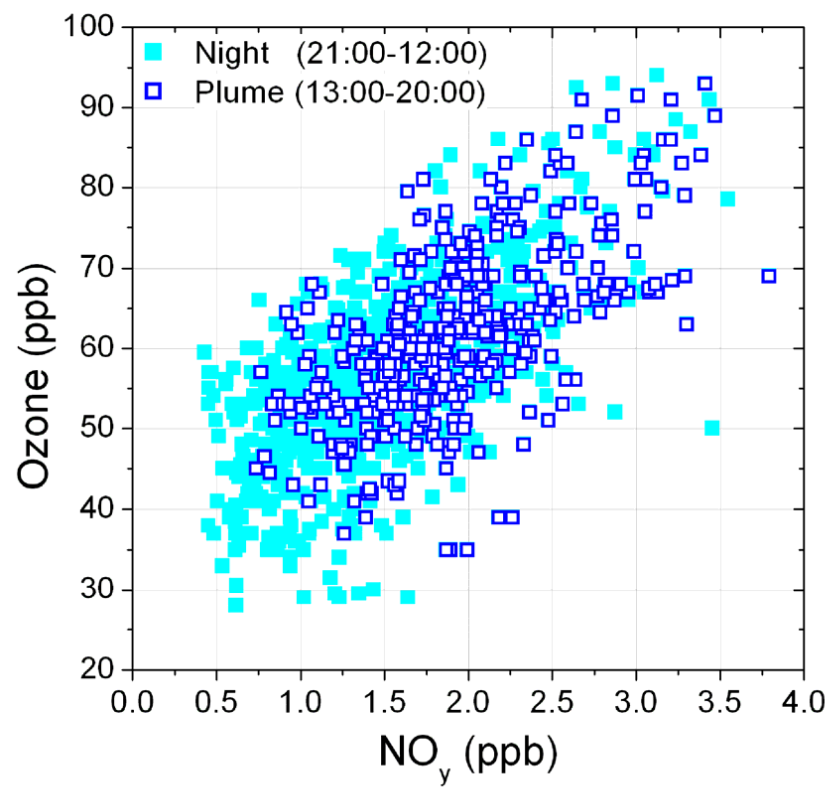

Fig. 18. Relationship between ozone ( $\mathrm{ppb}$ ) and reactive nitrogen (ppb) during summer months at Big Hill. Observations made during upslope flow in the plume are highlighted with open squares.

\subsection{Probability distributions of $\mathrm{NO}_{\mathrm{yi}}$ and ozone}

A great deal of insight can be gained by comparing observations made at Big Hill to corresponding measurements at the UC-BFRS site. Table 1 compiles data from the probability distributions shown in Fig. 19 for the two remote sites. As mentioned above, both sites lie along the Sacramento Lake Tahoe transect, but Big Hill is at a higher elevation, a greater distance from the city, and has less vegetation and cooler temperatures. Our analyses of the diurnal cycles at the two sites suggest that they sample similar airmasses during upslope flow and we restrict the comparison to times between 13:00-20:00 when both sites are strongly influenced by the Sacramento urban plume. Panels (a-f) of Fig. 19 show the normalized probability distributions for $30 \mathrm{~min}$ averages of the individual reactive nitrogen species, total $\mathrm{NO}_{\mathrm{y}}$, and $\mathrm{O}_{3}$ for both the Big Hill and the UC-BFRS sites. In the case of $\mathrm{NO}_{2}$, Big Hill values (median $0.33 \mathrm{ppb}$ ) are on average half those at the UC-BFRS with significantly fewer observations of more than $1 \mathrm{ppb}$. This means that the dilution and photooxidation of $\mathrm{NO}_{2}$ in the plume is quickly reducing its concentration several hours downwind of Sacramento. In this region, ozone production is expected to be $\mathrm{NO}_{\mathrm{x}}$-limited so it can also be inferred that instantaneous ozone production rates drop off quickly between the UC-BFRS and Big Hill.

Peroxy nitrates have a wider probability distribution at the UC-BFRS than at Big Hill and higher median observations. While absolute $\Sigma$ PNs concentrations are higher on average at UC-BFRS, the ratio of peroxy nitrates to $\mathrm{NO}_{2}$ is actually higher at Big Hill during the influence of the plume, likely due to the lower temperatures, stabilizing the reservoir species. At night, the ratio of $\Sigma \mathrm{PNs} / \mathrm{NO}_{2}$ becomes higher at UC-BFRS. More detailed modeling is required to explain these diurnal patterns quantitatively.

The probability distributions of alkyl nitrates are extremely similar at the two sites, but for different reasons. The breadth in the distribution at Big Hill derives from a stronger diurnal cycle whereas at the UC-BFRS, it results from greater day-to-day variability. Nevertheless, detailed comparison of the observations of alkyl nitrates at the two sites suggests that as a group these compounds are lost very slowly to deposition but are diluted when mixed with air from the free troposphere. Correlations between alkyl nitrates and both $\mathrm{CO}$ and $\mathrm{O}_{3}$ at UC-BFRS show that they are associated with polluted, upslope air, which also carries substantial biogenic emissions, and are formed in conjunction with ozone during photochemical activity. The deposition of most alkyl nitrates appears to be slow enough that a substantial fraction of what is produced in the plume stays in the atmosphere. From the perspective of nitrogen deposition, not enough is known about the behaviour of these compounds at the surface.

$\mathrm{HNO}_{3}$ concentrations are lower and less variable at Big Hill compared to the UC-BFRS. The flat diurnal profile for $\mathrm{HNO}_{3}$ at Big Hill suggests that this site is far enough from fresh $\mathrm{NO}_{\mathrm{x}}$ sources during the day that much of the $\mathrm{HNO}_{3}$ produced during oxidation has already had the chance to deposit before reaching the surface at high elevation sites, and that at night the site is strongly influenced by mixing from above. The UC-BFRS has higher daytime $\mathrm{NO}_{2}$ concentrations capable of generating strong local production of $\mathrm{HNO}_{3}$. The substantial reduction in daytime concentrations of $\mathrm{HNO}_{3}$ as the plume moves from Granite Bay upslope toward UC-BFRS and eventually Big Hill, require that significant amounts of $\mathrm{HNO}_{3}$ are lost from the boundary layer, either through deposition to the surface or export to the free troposphere.

The distribution of total $\mathrm{NO}_{\mathrm{y}}$ (Fig. 19e) at the two sites reflects the proximity of the UC-BFRS to Sacramento in both the higher average and the greater variability in concentrations. At the UC-BFRS, the total $\mathrm{NO}_{\mathrm{y}}$ in the plume varies between 1.0-5.5 ppb, whereas at Big Hill it ranges from 0.5$3.5 \mathrm{ppb}$. The data used in this analysis were not limited to days on which there was persistent upslope flow, thus some of the lower numbers likely result from days on which the urban plume did not influence the site. The greater variability in total $\mathrm{NO}_{\mathrm{y}}$ compared to any of its constituent species shows that the variability in $\mathrm{NO}_{\mathrm{yi}}$ is governed by the extent to which the total urban emissions are influencing these remote sites rather than by differences in partitioning among the available reactive nitrogen. For example, days with higher than average $\Sigma$ PNs tend to have higher $\Sigma$ ANs and $\mathrm{HNO}_{3}$ also. It is not clear from the local meteorological observations, which conditions, aside from wind direction and to a much lesser degree temperature, result in higher concentrations of reactive nitrogen being transported in the boundary layer along the western slope of the Sierra. 
Table 1. Data for June-October, 13:00-20:00 at the UC-BFRS and Big Hill. For each species listed the median, and 5th and 95th percentile values have been calculated in ppb.

\begin{tabular}{lllllll}
\hline & \multicolumn{5}{l}{ UC-BFRS } & \multicolumn{3}{l}{ Big Hill } \\
\cline { 2 - 7 } Species & $\begin{array}{l}\text { Median } \\
(\mathrm{ppb})\end{array}$ & $\begin{array}{l}5 \text { th } \\
\text { percentile }\end{array}$ & $\begin{array}{l}\text { 95th } \\
\text { percentile }\end{array}$ & $\begin{array}{l}\text { Median } \\
(\mathrm{ppb})\end{array}$ & $\begin{array}{l}\text { 5th } \\
\text { percentile }\end{array}$ & $\begin{array}{l}\text { 95th } \\
\text { percentile }\end{array}$ \\
\hline $\mathrm{NO}_{2}$ & 0.63 & 0.30 & 1.70 & 0.33 & 0.16 & 0.78 \\
$\Sigma \mathrm{PN}$ & 0.79 & 0.27 & 1.75 & 0.55 & 0.21 & 1.07 \\
$\Sigma \mathrm{AN}$ & 0.41 & 0.15 & 0.77 & 0.39 & 0.16 & 0.78 \\
$\mathrm{HNO}_{3}$ & 0.79 & 0.33 & 1.48 & 0.53 & 0.25 & 0.85 \\
$\mathrm{NO}_{y}$ & 2.68 & 1.57 & 4.92 & 1.84 & 1.05 & 2.99 \\
$\mathrm{O}_{3}$ & 61.5 & 40.7 & 88.4 & 60 & 45 & 82 \\
\hline
\end{tabular}

Finally, the distribution of ozone within the urban plume is shown for each site in Fig. 19f. The median ozone concentration at each site is very similar, but the UC-BFRS shows both more low values and more high values. The similarity between the two sites results partly from the fact that daytime ozone values are generally not more than a factor of two higher than the regional background, so mixing with the background drives concentrations toward a common value. From a regulatory standpoint, the UC-BFRS site is much more likely to exceed the federal 8-h ozone standard because of the significantly higher number of observations above $84 \mathrm{ppb}$. Comparison of ozone at the two sites suggests that the efficiency of ozone production has slowed considerably by the time the plume has reached the UC-BFRS, and it can no longer match the decreases in ozone due to dilution and deposition as the air moves toward Big Hill. This information can be used to ascertain the extent of influence of the urban plume on ozone in the region.

\section{Conclusions}

This paper describes the annual cycle of reactive nitrogen measurements made at Big Hill, a high elevation site on the western slope of the Sierra Nevada mountains in California. Throughout the year, terrain-driven winds bring air from the Central Valley upslope into the Sierra Nevada foothills, resulting in increased concentrations of primary and secondary pollutants in the region. The upslope transport is more persistent during summer months, resulting in net westerly flow at the surface. The increased radiation and emissions of biogenic VOC in the summer result in more rapid photochemical oxidation within the plume. During winter, anthropogenic emissions still influence the Big Hill site, but for a smaller portion of the day. In the winter, a more significant fraction of the $\mathrm{NO}_{\mathrm{y}}$ in the urban plume remains as $\mathrm{NO}_{2}$ reflecting the longer chemical lifetime. Intermittent burning events also in- fluenced winter measurements and resulted in elevated $\mathrm{NO}_{2}$, $\mathrm{NO}_{\mathrm{y}}$, and $\mathrm{PM}_{10}$ concentrations.

This analysis also synthesizes the summertime observations of reactive nitrogen and ozone made at Big Hill with two other sites in the outflow of the Sacramento urban plume. Comparison of the diurnal trends at the three sites shows that the distribution of reactive nitrogen in the region is a complicated function of emissions, photochemistry, mixing, transport and deposition. During daylight hours, the sites are connected by the prevailing westerly upslope flow. When the plume reaches Big Hill it has lower concentrations of $\mathrm{NO}_{2}, \Sigma \mathrm{PNs}$, and $\mathrm{HNO}_{3}$ than at UC-BFRS. While the absolute amounts of $\Sigma \mathrm{PNs}$ and $\mathrm{HNO}_{3}$ are lower at Big Hill and Blodgett, the concentrations normalized to the $\mathrm{NO}_{2}$ precursor are higher, showing that the plume has been further oxidized by the time it gets to Big Hill.

The strong diurnal cycles in $\mathrm{HNO}_{3}$ at Granite Bay and the UC-BFRS suggest that a large sink to deposition competes with rapid production in the boundary layer. As the plume reaches Big Hill, a significant fraction of the $\mathrm{HNO}_{3}$ produced along the way has been lost to deposition and dilution and decreasing concentrations of $\mathrm{NO}_{2}$ result in relatively low local production. During the night, descending air from the free troposphere contains nearly as much $\mathrm{HNO}_{3}$ as that found in the shallow urban boundary layer at Granite Bay. Because peroxy nitrates are in thermal equilibrium with $\mathrm{NO}_{2}(\tau \sim 1 \mathrm{~h})$, changes in concentrations of $\Sigma$ PNs between the UC-BFRS and Big Hill are a balance between increased sequestration due to lower temperatures and release of $\mathrm{NO}_{2}$ to compensate for the rapid loss of $\mathrm{NO}_{2}$ in the plume. Temperature plays a large role in determining the fraction of nitrogen oxide radicals that are stored as $\Sigma$ PNs in the plume. Low temperatures decrease the rate of ozone production in the regional boundary layer, but may result in the export of more $\mathrm{NO}_{\mathrm{y}}$ in a reservoir form capable of leading to ozone production further downwind. A recent analysis of the effect of mountain venting on photochemistry in the free troposphere shows that subsequent production and loss of ozone depends 

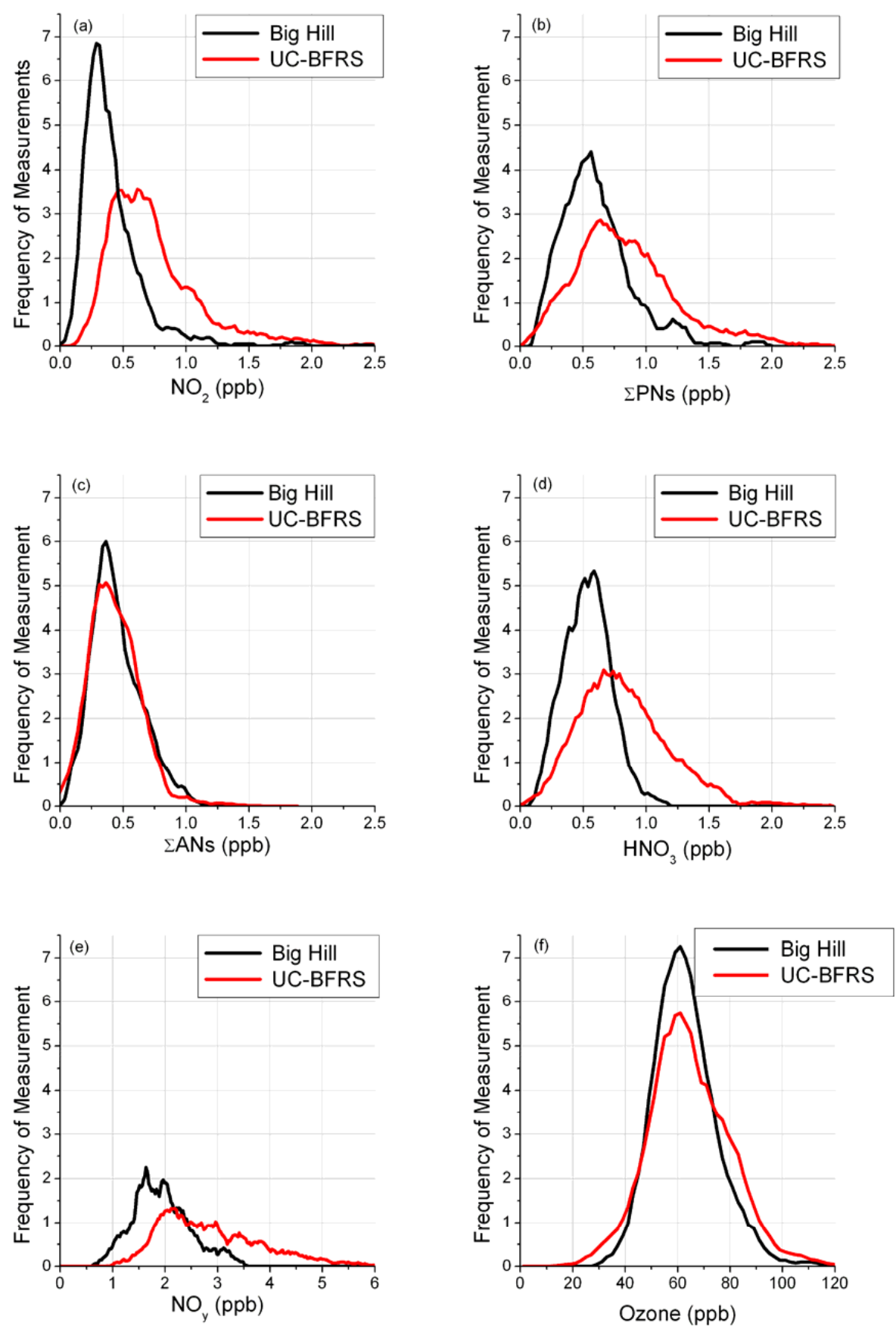

Fig. 19. Overlaid normalized probability distributions (frequency of measurements in $\%$ ) for half hour averages of $\mathrm{NO}_{\mathrm{yi}}, \mathrm{NO}_{\mathrm{y}}$ and $\mathrm{O}_{3}$ observations made during the summer plume at the UC-BFRS (red) and Big Hill (black).

critically on the concentration of nitrogen oxides and peroxy acyl nitrates injected from the boundary layer (Henne et al., 2005). Our observations show that at Big Hill, the site further downwind and upslope, a greater fraction of $\mathrm{NO}_{2}$ has been sequestered in $\Sigma$ PNs, suggesting these species are an important constituent of the reactive nitrogen that may be ultimately injected into the free troposphere.
Interestingly, the concentrations of $\mathrm{O}_{3}$ and $\Sigma$ ANs in the plume at Big Hill are comparable to those at UC-BFRS, perhaps offset by an hour. This can be rationalized by a comparison of sources and sinks of these compounds, and those of $\mathrm{HNO}_{3}$ and $\Sigma$ PNs. While the production rate of $\mathrm{HNO}_{3}$ falls off sharply as the plume advects and dilutes, the optimal range for the production of ozone and organic nitrates 
is likely found further downwind, both due to a decrease in nitrogen oxides (to a more optimal value), and an increase in biogenic VOC. The deposition rates of ozone and $\Sigma$ ANs are believed to be significantly lower than that of $\mathrm{HNO}_{3}$ so they persist for longer in the plume once they have been produced. Unlike $\Sigma$ PNs, they have no rapid decomposition pathway back to $\mathrm{NO}_{\mathrm{x}}$ and therefore, once produced, cannot respond to decreasing $\mathrm{NO}_{2}$ as the plume evolves. The measurements imply that $\Sigma$ ANs could be a significant fraction of the $\mathrm{NO}_{\mathrm{y}}$ exported to the free troposphere, a contribution that is not included in many current analyses (e.g. Parrish et al., 2004; Henne et al., 2005).

Acknowledgements. Measurements at Big Hill were made in collaboration with the California Air Resources Board under Contract No. 01-327. We gratefully acknowledge that support and the U.S. Department of Energy support for measurements at Granite Bay under contract AC03-76SF0009. Observations at the UC-BFRS were supported by NSF ATM-0138669. We thank M. McKay and A. Goldstein for assistance with meteorological and ozone data from the UC-BFRS and Granite Bay. We are grateful to the Eureka Union School District, Sierra Pacific Industries, and the United States Forest Service for the use of the sites.

Edited by: A. Hofzumahaus

\section{References}

Beine, H. J. and Krognes, T.: The seasonal cycle of peroxyacetyl nitrate (PAN) in the European Arctic, Atmos. Environ., 34, 933940, 2000.

Bertram, T. H. and Cohen, R. C.: A prototype instrument for the real time detection of semi-volatile organic and inorganic nitrate aerosol, American Geophysical Union Fall Meeting, San Francisco, A51F-0740, 2003.

Blumenthal, D. L., White, W. H., and Smith, T. B.: Anatomy of a Los-Angeles smog episode - pollutant transport in daytime sea breeze regime, Atmos. Environ., 12, 893-907, 1978.

Brown, S. S., Ryerson, T. B., Wollny, A. G., Brock, C. A., Peltier, R., Sullivan, A. P., Weber, R. J., Dube, W. P., Trainer, M., Meagher, J. F., Fehsenfeld, F. C., and Ravishankara, A. R.: Variability in nocturnal nitrogen oxide processing and its role in regional air quality, Science, 311, 67-70, 2006.

Bytnerowicz, A., Carroll, J. J., Takemoto, B. K., Miller, P. R., Fenn, M. E., and Musselman, R. C.: Distribution and transport of air pollutants to vulnerable California ecosystems, in: Integrated Assessment of Ecosystem Health, Ann Arbor Press, Chelsea, MI. 93-118, 2000.

Carroll, J. J. and Dixon, A. J.: Regional scale transport over complex terrain, a case study: tracing the Sacramento plume in the Sierra Nevada of California, Atmos. Environ., 36, 3745-3758, 2002.

Cleary, P. A., Wooldridge, P. J., and Cohen, R. C.: Laser-induced fluorescence detection of atmospheric $\mathrm{NO}_{2}$ with a commercial diode laser and a supersonic expansion, Appl. Opt., 41, 69506956, 2002.

Cleary, P. A., Murphy, J. G., Wooldridge, P. J., Day, D. A., Millet, D. B., Goldstein, A. H., and Cohen, R. C.: Observations of total alkyl nitrates within the Sacramento urban plume, Atmos. Chem. Phys. Discuss., 5, 4801-4843, 2005,

http://www.atmos-chem-phys-discuss.net/5/4801/2005/.

Darnall, K. R., Carter, W. P. L., Winer, A. M., Lloyd, A. C., and Pitts, J. N.: Importance of $\mathrm{RO}_{2}+\mathrm{NO}$ in alkyl nitrate formation from C4-C6 alkane photooxidations under simulated atmospheric conditions, J. Phys. Chem., 80, 1948-1950, 1976.

Day, D. A., Wooldridge, P. J., Dillon, M. B., Thornton, J. A., and Cohen, R. C.: A Thermal Dissociation-Laser Induced Fluorescence instrument for in situ detection of $\mathrm{NO}_{2}$, Peroxy(acyl)nitrates, Alkylnitrates and $\mathrm{HNO}_{3}$, J. Geo. Res.-A., 107, 4046, doi:10.1029/2001JD000779, 2002.

Day, D. A.: Observations of $\mathrm{NO}_{2}$, Total Peroxynitrates, Total Alkyl Nitrates, and $\mathrm{HNO}_{3}$ in the Mid-Sierras and Sacramento Plume Using Thermal Dissociation - Laser Induced Fluorescence, University of California, 207 p., 2003.

Day, D. A., Dillon, M. B., Wooldridge, P. J., Rosen, R. S., Wood, E. C., and Cohen, R. C.: On alkyl nitrates, $\mathrm{O}_{3}$ and the "missing NOy", J. Geo. Res.-A., 108, 4501, doi:10.1029/2003JD003685, 2003.

Dillon, M. B.: The Chemical Evolution of the Sacramento Urban Plume, University of California, 205 p., 2002.

Dillon, M. B., Lamanna, M. S., Schade, G. W., Goldstein, A. H., and Cohen, R. C.: Chemical evolution of the Sacramento urban plume: Transport and oxidation, J. Geo. Res.-A., 107, 4045, doi:10.1029/2001JD000969, 2002.

Fahey, D. W., Hubler, G., Parrish, D. D., Williams, E. J., Norton, R. B., Ridley, B. A., Singh, H. B., Liu, S. C., and Fehsenfeld, F. C.: Reactive Nitrogen Species in the Troposphere - Measurements of $\mathrm{NO}, \mathrm{NO}_{2}, \mathrm{HNO}_{3}$, Particulate Nitrate, Peroxyacetyl Nitrate (PAN), $\mathrm{O}_{3}$, and Total Reactive Odd Nitrogen $\left(\mathrm{NO}_{y}\right)$ at Niwot Ridge, Colorado, J. Geophys. Res.-A., 91, 9781-9793, 1986.

Flocke, F., Volzthomas, A., and Kley, D.: Measurements of Alkyl Nitrates in Rural and Polluted Air Masses, Atmos Environ., 25, 1951-1960, 1991.

Geyer, A., Alicke, B., Konrad, S., Schmitz, T., Stutz, J. and Platt, U.: Chemistry and oxidation capacity of the nitrate radical in the continental boundary layer near Berlin, J. Geophys. Res.-A., 106, 8013-8025, 2001.

Giacopelli, P., Ford, K., Espada, C., and Shepson, P. B.: Comparison of the measured and simulated isoprene nitrate distributions above a forest canopy, J. Geophys. Res.-A., 110, D01304, doi:10.1029/2004JD005123, 2005.

Hayden, K. L., Anlauf, K. G., Hastie, D. R., and Bottenheim, J. W.: Partitioning of reactive atmospheric nitrogen oxides at an elevated site in southern Quebec, Canada, J. Geophys. Res.-A., 108, 4603, doi:10.1029/2002JD003188, 2003.

Henne, S., Dommen, J., Neininger, B., Reimann, S., Staehelin, J., and Prevot, A. S. H.: Influence of mountain venting in the Alps on the ozone chemistry of the lower free troposphere and the European pollution export, J. Geophys. Res.-A., 110, D22307, doi:10.1029/2005JD005936, 2005.

Hudman, R. C., Jacob, D. J., Cooper, O. R., Evans, M. J., Heald, C. L., Park, R. J., Fehsenfeld, F., Flocke, F., Holloway, J., Hubler, G., Kita, K., Koike, M., Kondo, Y., Neuman, A., Nowak, J., Oltmans, S., Parrish, D., Roberts, J. M., and Ryerson, T.: Ozone production in transpacific Asian pollution plumes and implications for ozone air quality in California, J. Geophys. Res.-A., 109, D23S10, doi:10.1029/2004JD004974, 2004. 
Kimura, F. and Kuwagata, T.: Horizontal Heat Fluxes over Complex Terrain Computed Using a Simple Mixed-Layer Model and a Numerical-Model, J. Appl. Meteorol., 34, 549-558, 1995.

Kurpius, M. R. and Goldstein, A. H.: Gas-phase chemistry dominates $\mathrm{O}_{3}$ loss to a forest, implying a source of aerosols and hydroxyl radicals to the atmosphere, Geophys. Res. Lett., 30, 1371, doi:10.1029/2002GL016785, 2003.

Li, Q. B., Jacob, D. J., Bey, I., Palmer, P. I., Duncan, B. N., Field, B. D., Martin, R. V., Fiore, A. M., Yantosca, R. M., Parrish, D. D., Simmonds, P. G., and Oltmans, S. J.: Transatlantic transport of pollution and its effects on surface ozone in Europe and North America, J. Geophys. Res.-A., 107, D13, doi:10.1029/2001JD001422, 2002.

Li, Q. B., Jacob, D. J., Munger, J. W., Yantosca, R. M., and Parrish, D. D.: Export of $\mathrm{NO}_{\mathrm{y}}$ from the North American boundary layer: Reconciling aircraft observations and global model budgets, J. Geophys. Res.-A., 109, D02313, doi:10.1029/2003JD004086, 2004.

Liang, J. Y., Horowitz, L. W., Jacob, D. J., Wang, Y. H., Fiore, A. M., Logan, J. A., Gardner, G. M., and Munger, J. W.: Seasonal budgets of reactive nitrogen species and ozone over the United States, and export fluxes to the global atmosphere, J. Geophys. Res.-A., 103, 13 435-13 450, 1998.

Moody, J. L., Munger, J. W., Goldstein, A. H., Jacob, D. J., and Wofsy, S. C.: Harvard forest regional-scale air mass composition by Patterns in Atmospheric Transport History (PATH), J. Geophys. Res.-A., 103, 13 181-13 194, 1998.

Munger, J. W., Fan, S. M., Bakwin, P. S., Goulden, M. L., Goldstein, A. H., Colman, A. S., and Wofsy, S. C.: Regional budgets for nitrogen oxides from continental sources: Variations of rates for oxidation and deposition with season and distance from source regions, J. Geophys. Res.-A., 103, 8355-8368, 1998.

Neuman, J. A., Nowak, J. B., Brock, C. A., Trainer, M., Fehsenfeld, F. C., Holloway, J. S., Hubler, G., Hudson, P. K., Murphy, D. M., Nicks, D. K., Orsini, D., Parrish, D. D., Ryerson, T. B., Sueper, D. T., Sullivan, A., and Weber, R.: Variability in ammonium nitrate formation and nitric acid depletion with altitude and location over California, J. Geophys. Res.-A., 108, 4557, doi:10.1029/2003JD003616, 2003.

Ohtani, R.: Detection of water vapor variations driven by thermallyinduced local circulations using the Japanese continuous GPS array, Geophys. Res. Lett., 28, 151-154, 2001.

Parrish, D. D., Ryerson, T. B., Holloway, J. S., Neuman, J. A., Roberts, J. M., Williams, J., Stroud, C. A., Frost, G. J., Trainer, M., Hubler, G., Fehsenfeld, F. C., Flocke, F., and Weinheimer, A. J.: Fraction and composition of $\mathrm{NO}_{\mathrm{y}}$ transported in air masses lofted from the North American continental boundary layer, J. Geophys. Res.-A., 109, D09302, doi:10.1029/2003JD004226, 2004.

Ryerson, T. B., Trainer, M., Holloway, J. S., Parrish, D. D., Huey, L. G., Sueper, D. T., Frost, G. J., Donnelly, S. G., Schauffler, S., Atlas, E. L., Kuster, W. C., Goldan, P. D., Hubler, G., Meagher, J. F., and Fehsenfeld, F. C.: Observations of ozone formation in power plant plumes and implications for ozone control strategies, Science, 292, 719-723, 2001.

Shepson, P. B., Anlauf, K. G., Bottenheim, J. W., Wiebe, H. A., Gao, N., Muthuramu, K., and Mackay, G. I.: Alkyl Nitrates and Their Contribution to Reactive Nitrogen At a Rural Site in Ontario, Atmos Environ., 27, 2251-2251, 1993.
Singh, H. B.: Reactive Nitrogen In The Troposphere, Environ. Sci. Technol., 21, 320-327, 1987.

Tanimoto, H., Furutani, H., Kato, S., Matsumoto, J., Makide, Y., and Akimoto, H.: Seasonal cycles of ozone and oxidized nitrogen species in northeast Asia - 1. Impact of regional climatology and photochemistry observed during RISOTTO 1999-2000, J. Geophys. Res.-A., 107, 4747, doi:10.1029/2001JD001496, 2002.

Thornberry, T., Carroll, M. A., Keeler, G. J., Sillman, S., Bertman, S. B., Pippin, M. R., Ostling, K., Grossenbacher, J. W., Shepson, P. B., Cooper, O. R., Moody, J. L., and Stockwell, W. R.: Observations of reactive oxidized nitrogen and speciation of $\mathrm{NO}_{\mathrm{y}}$ during the PROPHET summer 1998 intensive, J. Geophys. Res.A., 106, 24 359-24 386, 2001.

Thornton, J. A., Wooldridge, P. J., and Cohen, R. C.: Atmospheric $\mathrm{NO}_{2}$ : In situ laser-induced fluorescence detection at parts per trillion mixing ratios, Analyt. Chem., 72, 528-539, 2000.

Thornton, J. A., Wooldridge, P. J., Cohen, R. C., Williams, E. J., Hereid, D., Fehsenfeld, F. C., Stutz, J. and Alicke, B.: Comparisons of in situ and long path measurements of $\mathrm{NO}_{2}$ in urban plumes, J. Geophys. Res.-A., 108, 4496, doi:10.1029/2003JD003559, 2003.

Trainer, M., Parrish, D. D., Buhr, M. P., Norton, R. B., Fehsenfeld, F. C., Anlauf, K. G., Bottenheim, J. W., Tang, Y. Z., Wiebe, H. A., Roberts, J. M., Tanner, R. L., Newman, L., Bowersox, V. C., Meagher, J. F., Olszyna, K. J., Rodgers, M. O., Wang, T., Berresheim, H., Demerjian, K. L., and Roychowdhury, U. K.: Correlation Of Ozone With $\mathrm{NO}_{\mathrm{y}}$ In Photochemically Aged Air, J. Geophys. Res.-A., 98, 2917-2925, 1993.

Trainer, M., Ridley, B. A., Buhr, M. P., Kok, G., Walega, J., Hubler, G., Parrish, D. D. and Fehsenfeld, F. C.: Regional Ozone and Urban Plumes in the Southeastern United-States - Birmingham, a Case-Study, J. Geophys. Res.-A., 100, 18 823-18 834, 1995.

van Ooy, D. J. and Carroll, J. J.: The spatial variation of ozone climatology on the western slope of the Sierra Nevada, Atmos. Environ., 29, 1319-1330, 1995.

White, W. H., Anderson, J. A., Blumenthal, D. L., Husar, R. B., Gillani, N. V., Husar, J. D., and Wilson, W. E.: Formation and Transport of Secondary Air-Pollutants - Ozone and Aerosols in St-Louis Urban Plume, Science, 194, 187-189, 1976.

Wood, E. C., Bertram, T. H., Wooldridge, P. J., and Cohen, R. C.: Measurements of $\mathrm{N}_{2} \mathrm{O}_{5}, \mathrm{NO}_{2}$, and $\mathrm{O}_{3}$ east of the San Francisco Bay, Atmos Chem. Phys., 5, 483-491, 2005.

Zaveri, R. A., Berkowitz, C. M., Kleinman, L. I., Springston, S. R., Doskey, P. V., Lonneman, W. A., and Spicer, C. W.: Ozone production efficiency and $\mathrm{NO}_{\mathrm{x}}$ depletion in an urban plume: Interpretation of field observations and implications for evaluating $\mathrm{O}_{3}-\mathrm{NO}_{\mathrm{x}}$-VOC sensitivity, J. Geophys. Res.-A., 108, 4436, doi:10.1029/2002JD003144, 2003.

Zellweger, C., Forrer, J., Hofer, P., Nyeki, S., Schwarzenbach, B., Weingartner, E., Ammann, M., and Baltensperger, U.: Partitioning of reactive nitrogen $\left(\mathrm{NO}_{y}\right)$ and dependence on meteorological conditions in the lower free troposphere, Atmos Chem. Phys., 3, 779-796, 2003.

Zhong, S. Y., Whiteman, C. D., and Bian, X. D.: Diurnal evolution of three-dimensional wind and temperature structure in California's Central Valley, J. Appl. Meteorol., 43, 1679-1699, 2004. 